\title{
Exploring the cytotoxic activity of new phenanthroline salicylaldimine Zn(II) complexes
}

\author{
Cristina P. Matos ${ }^{\mathrm{a}}$, Yemataw Addis ${ }^{\mathrm{a}, \mathrm{b}}$, Patrique Nunes ${ }^{\mathrm{a}}$, Sónia Barroso ${ }^{\mathrm{a}, 1}$, Irina Alho ${ }^{\mathrm{c}}$, \\ Marta Martins $^{\mathrm{c}}$, António P.A. Matos ${ }^{\mathrm{d}}$, Fernanda Marques ${ }^{\mathrm{e}}$, Isabel Cavaco ${ }^{\mathrm{a}, \mathrm{b}}$, João Costa Pessoa ${ }^{\mathrm{a}, *}$, \\ Isabel Correia ${ }^{a, *}$ \\ ${ }^{a}$ Centro de Química Estrutural, Departamento de Engenharia Química, Instituto Superior Técnico, Universidade de Lisboa, Av Rovisco Pais, $1049-001$ Lisboa, Portugal \\ ${ }^{\mathrm{b}}$ Departamento de Química e Farmácia, Universidade do Algarve, Campus de Gambelas, 8005-139 Faro, Portugal \\ ${ }^{\mathrm{c}}$ Instituto de Medicina Molecular - João Lobo Antunes, Faculdade de Medicina, Universidade de Lisboa, Av. Professor Egas Moniz, 1649-028 Lisboa, Portugal \\ ${ }^{\mathrm{d}}$ Centro de Investigação Interdisciplinar Egas Moniz, Campus Universitário, Quinta da Granja, Monte de Caparica, 2829-511 Caparica, Portugal \\ ${ }^{\mathrm{e}}$ Centro de Ciências e Tecnologias Nucleares, Instituto Superior Técnico, Universidade de Lisboa, Estrada Nacional 10, 2695-066 Bobadela LRS, Portugal.
}

\section{A R T I C L E I N F O}

\section{Keywords:}

Zinc(II) complexes

Polypyridyl ligands

Salicylaldimines

Anticancer activity

ROS

Lipid peroxides

\begin{abstract}
A B S T R A C T
Zinc(II) complexes bearing $N$-salicylideneglycinate (Sal-Gly) and 1,10-phenanthroline (phen) or phenanthroline derivatives [NN =5-chloro-1,10-phenanthroline, 5-amine-1,10-phenanthroline (amphen), 4,7-diphenyl-1,10-phenanthroline (Bphen) and 5,6-epoxy-5,6-dihydro-1,10-phenanthroline] are synthesized. Complexes formulated as $\left[\mathrm{Zn}(\mathrm{NN})_{2}\left(\mathrm{H}_{2} \mathrm{O}\right)_{2}\right]^{2+}(\mathrm{NN}=$ phen and amphen), are also prepared. The cytotoxicity of the compounds is evaluated towards a panel of human cancer cells: ovarian (A2780), breast (MCF7) and cervical (HeLa), as well as non-tumoral V79 fibroblasts. All compounds display higher cytotoxicity than cisplatin $\left(\mathrm{IC}_{50}=22.5 \pm 5.0 \mu \mathrm{M}\right)$ towards ovarian cells, showing $\mathrm{IC}_{50}$ values in the low micromolar range. Overall, all compounds show higher selectivity for the A2780 cells than for the nontumoral cells and higher selectivity indexes $\left(\mathrm{IC}_{50}(\mathrm{~V} 79) / / \mathrm{C}_{50}(\mathrm{~A} 2780)\right.$ than cisplatin. [Zn $\left.(\mathrm{Sal}-\mathrm{Gly})(\mathrm{NN})\left(\mathrm{H}_{2} \mathrm{O}\right)\right]$ complexes induce caspase-dependent apoptosis in A2780 cells, except [ $\left.\mathrm{Zn}(\mathrm{Sal}-\mathrm{Gly})(\mathrm{Bphen})\left(\mathrm{H}_{2} \mathrm{O}\right)\right]$, one of the most cytotoxic of the series. The cellular uptake in the ovarian cells analyzed by Inductively Coupled Plasma mass spectrometry indicates different $\mathrm{Zn}$ distribution profiles. Transmission electronic microscopy shows mitochondria alterations and apoptotic features consistent with caspase activation; cells incubated with $\left[\mathrm{Zn}(\mathrm{Sal}-\mathrm{Gly})(\right.$ amphen $\left.)\left(\mathrm{H}_{2} \mathrm{O}\right)\right]$ present additional nuclear membrane alterations in agreement with significant association with the nucleus. The increase of reactive oxygen species and lipid peroxidation forms could be related to apoptosis induction. $\left[\mathrm{Zn}(\mathrm{NN})_{2}\left(\mathrm{H}_{2} \mathrm{O}\right)_{2}\right]^{2+}$ complexes have high ability to bind DNA through intercalation/groove binding, and circular dichroism data suggests that the main type of species that interact with DNA is $[\mathrm{Zn}(\mathrm{NN})]^{2+}$. Studies varying the $\%$ of fetal bovine serum $(1-15 \%)$ in cell media show that albumin binding decreases the complex activity, indicating that distinct speciation of $\mathrm{Zn}$ - and phen-containing species in cell media may affect the cytotoxicity.
\end{abstract}

\section{Introduction}

The success of platinum-based compounds as anticancer metallodrugs paved the way to an area of intense research, whose quest is to find new and effective metal-based chemotherapeutic agents with improved clinical outcomes. In fact, cisplatin is an example of success, although presenting some constraints as a safe and effective metal-based anticancer drug. Drug toxicity and acquired resistance during treatment are some of these constraints.
The development of metal-based drugs that make use of bioessential elements is an area of current interest. The underlying principle is that metal ion homeostasis of such metals will be better dealt by human physiology and cause less damaging side effects than when using compounds based on non-essential metals $[1,2]$. Zinc is, after iron, the second most abundant transition metal in the human body. Zinc is known to be present in thousands of proteins, required for the catalytic activity of over 200 enzymes [3], and to perform roles related to immune function, protein synthesis, DNA

\footnotetext{
* Corresponding authors.

E-mail addresses: joao.pessoa@tecnico.ulisboa.pt (J. Costa Pessoa), icorreia@tecnico.ulisboa.pt (I. Correia).

${ }^{1}$ Current address: MARE - Marine and Environmental Sciences Centre, ESTM, Polytechnic Institute of Leiria, Peniche, Portugal.
} 
synthesis and cell division, just to name a few examples [4,5]. Due to zinc's numerous physiological roles, $\mathrm{Zn}$ (II) complexes have been used as DNA binding compounds [6-8], nuclease-mimics [9], radioprotective agents [10], insulin-mimics [11] and antimicrobial agents [12]. Lately, Zn(II) complexes have been gathering attention as potential anticancer drugs with lower toxicity in vivo, and probably distinct targets and modes of action from the classical Ptmetallodrugs [13-16]. It is clear that zinc offers interesting chemical and biochemical properties for the development of anticancer drugs. Combination of the metal ion with bioactive and/or bioavailable organic ligands is a strategy that may contribute to obtain an effective and more selective metallodrug.

Schiff base metal complexes have been extensively studied owing to their modular easy preparation and versatility [17]. The use of salicylaldehyde amino acid derived Schiff bases with N,O donor sets plays an important role in coordination chemistry related to catalysis and enzymatic reactions that may be potentially used for many biological applications [18-20]. Metal complexes based on polypyridyl ligands and metal ions such as $\mathrm{Zn}$ (II) [8], Cu (II) $[19,21-26], \mathrm{V}$ (IV) $[18,27]$, and Ru(II) $[28,29]$, have been intensively studied for their features as DNA intercalators, showing a diverse spectrum of DNA binding/cleavage ability and cytotoxicity against cancer cell lines. Moreover, some complexes with phenanthroline derivatives were reported to be active against various pathologic conditions including microbial and fungal infections in addition to cancer diseases [30-32]. Nuclear DNA has been considered an important target for some of these complexes. However, more recent studies have shown that the main anticancer action could be attributed to other factors, such as ROS (reactive oxygen species) production triggering mitochondria-mediated apoptosis and also indicating the dependence of the cytotoxic effects on the accumulation of the complexes in different cell compartments [33].

Our group has been involved in the search for prospective metal-based anticancer drugs. Our approach has included the use of ternary complexes of vanadium(IV) and copper(II) with Schiff bases or thiosemicarbazones and polypyridyls [18-20]. The presence of the polypyridyl aromatic heterocycle seems to be crucial for the anticancer activity, and their binding to $\mathrm{Zn}$ (II) may modulate their activity. Within this objective two groups of complexes were prepared: $\mathrm{Zn}(\mathrm{II})$-complexes with general formulation [Zn(Sal-Gly) $(\mathrm{NN})\left(\mathrm{H}_{2} \mathrm{O}\right)$ ], with Sal-Gly $=\mathrm{N}$-salicylideneglycinate, $\mathrm{NN}=1,10$-phenanthroline (phen), 5-chloro-1,10-phenanthroline (Clphen), 5amine-1,10-phenanthroline (amphen), 5,6-epoxy-5,6-dihydro-1,10phenanthroline (epoxyphen) and 4,7-diphenyl-1,10-phenanthroline (Bphen); and $\mathrm{Zn}(\mathrm{II})$-complexes with formulation $\left[\mathrm{Zn}(\mathrm{NN})_{2}\right]^{2+}$ with $\mathrm{NN}=$ phen and amphen (Fig. 1). These compounds and their solution behavior were studied by spectroscopic methods, and evaluated for their antiproliferative action against several cell lines. Plausible mechanisms of action were assessed with biochemical techniques.

\section{Experimental part}

\subsection{Materials}

Glycine (Gly) was purchased from BDH Chemicals, salicylaldehyde from Aldrich and phenanthrolines from Alfa Aesar or SigmaAldrich. The metal precursors $\mathrm{Zn}\left(\mathrm{CH}_{3} \mathrm{COO}\right)_{2} \cdot 2 \mathrm{H}_{2} \mathrm{O}$ and $\mathrm{Zn}$ $\left(\mathrm{NO}_{3}\right)_{2} \cdot 4 \mathrm{H}_{2} \mathrm{O}$ were from Panreac and Fluka, respectively. 4-(2Hydroxyethyl)piperazine-1-ethanesulfonic acid (HEPES) was purchased from Sigma. Solvents were from Sigma-Aldrich, CarloErba, Panreac or Fisher and used as received. Phosphate buffered saline (PBS) was purchased from Sigma-Aldrich as tablets readily soluble in water (deionized water) giving $0.010 \mathrm{M}$ in phosphate (and $\mathrm{NaCl} 0.138 \mathrm{M}$; $\mathrm{KCl} 0.0027 \mathrm{M}$ ), $\mathrm{pH} 7.4$ at $25^{\circ} \mathrm{C}$. HEPES $10 \mathrm{mM}$ buffer solutions were prepared in deionized water with $\mathrm{pH} 7.4$ at $25^{\circ} \mathrm{C}$. Calf thymus DNA (ctDNA) was from Sigma-Aldrich. All materials used were either p.a. or reagent grade. Cell media and supplements were purchased from Gibco, Thermo Fisher Scientific. Tumor cells A2780 (ovarian), MCF7 (breast), HeLa (cervical) and a non-tumorigenic cell line V79 (Chinese hamster fibroblasts) were acquired from Sigma-Aldrich (A2780) and ATCC (American Type Culture Collection).

\subsection{Instrumentation}

Electronic absorption spectra (UV-Vis) were recorded with a Perkin Elmer Lambda 35 spectrometer with $10.0 \mathrm{~mm}$ quartz cuvettes. ${ }^{1} \mathrm{H}$ and ${ }^{13} \mathrm{C}$ NMR spectra were obtained on Bruker Avance $+400 \mathrm{MHz}$ or $300 \mathrm{MHz}$ Spectrometers and ${ }^{1} \mathrm{H}$ and ${ }^{13} \mathrm{C}$ NMR chemical shifts $(\delta)$ are expressed in ppm relative to $\mathrm{Me}_{4} \mathrm{Si}$ or the deuterated solvent residual peak. Elemental analyses were carried out on a FISONS EA 1108 CHNS-O apparatus. Electrospray lonization mass spectra (ESI-MS) were measured on a 500-MS Varian Ion Trap Mass Spectrometer. The infrared spectra were recorded on a JASCO FT/IR 4100 spectrophotometer. Circular Dichroism (CD) spectra were measured on a Jasco J-720-CD spectropolarimeter (Jasco, Hiroshima, Japan) with a $175-800 \mathrm{~nm}$ photomultiplier (EXEL-308) using a $10.0 \mathrm{~mm}$ quartz cuvette. Fluorescence measurements were carried out on a SPEX ${ }^{\circledR}$ Fluorolog spectrofluorimeter (Horiba Jobin Yvon) in a FL3-11 configuration, equipped with a Xenon lamp and in a $10.0 \times 10.0 \mathrm{~mm}$ quartz cuvette. The instrumental response was corrected by means of a correction function provided by the manufacturer. The fluorimetric experiments were carried out at room temperature and are all steady-state measurements. The X-ray Powder Diffraction (XRPD) data collection was done in a D8 Advance Bruker AXS $\theta-2 \theta$ diffractometer, with a copper radiation source ( $\mathrm{Cu} \mathrm{K \alpha}, \lambda=1.5406 \AA$ ) and a secondary monochromator.

\subsection{Synthesis}

\subsection{1. $\left[\mathrm{Zn}(\mathrm{Sal}-\mathrm{Gly})(\mathrm{NN})\left(\mathrm{H}_{2} \mathrm{O}\right)\right]$ complexes}

Complexes were synthesized using the following general procedure: to an ethanolic (or methanolic) solution of glycine ( $1 \mathrm{mmol}$ ) and $\mathrm{NaOH}(1 \mathrm{mmol})$ salicylaldehyde $(1 \mathrm{mmol})$ was added. The resulting yellow solution was stirred for $30 \mathrm{~min}$ at room temperature and a solution of $\mathrm{Zn}\left(\mathrm{CH}_{3} \mathrm{COO}\right)_{2} \cdot 2 \mathrm{H}_{2} \mathrm{O}(1 \mathrm{mmol}$ in $5 \mathrm{~mL}$ of water) was added dropwise. The $\mathrm{pH}$ was adjusted to 7 with $1 \mathrm{M} \mathrm{NaOH}$ and the mixture was stirred at room temperature for $1 \mathrm{~h}$. The polypyridyl $(1 \mathrm{mmol})$ in ethanol $(10 \mathrm{~mL})$ was then added and the resulting solution stirred at room temperature for $1 \mathrm{~h}$, subsequently concentrated and left overnight at $4^{\circ} \mathrm{C}$. The precipitate obtained was filtered, washed with cold ethanol and diethyl ether and dried in vacuum.

[Zn(Sal-Gly)(phen)( $\left.\mathrm{H}_{2} \mathrm{O}\right)$ ] 1. Yield: $62 \%$. Elemental Anal. Calc. for $\mathrm{C}_{21} \mathrm{H}_{17} \mathrm{~N}_{3} \mathrm{O}_{4} \mathrm{Zn}$ : C, 57.22; $\mathrm{H}, 3.89 ; \mathrm{N}, 9.53$. Found: $\mathrm{C}, 57.31 ; \mathrm{H}$, 3.85; N, 9.37. ESI MS $m / z$ : [Calculated (Found)]: 420.04 (419.23) (100\%) [Zn(Sal-Gly)(phen)-H] ${ }^{-} ; 422.04$ (422.12) (15\%) [Zn(Sal-Gly) (phen) $+\mathrm{H}]^{+} .{ }^{1} \mathrm{H}$ NMR $\left(\mathrm{d}_{6}-\mathrm{DMSO}, \delta / \mathrm{ppm}\right): 8.99(\mathrm{~d}, 2 \mathrm{H}) ; 8.77(\mathrm{~d}, 2 \mathrm{H})$; $8.55(\mathrm{~s}, 1 \mathrm{H}) ; 8.18(\mathrm{~s}, 2 \mathrm{H}) ; 7.95(\mathrm{~m}, 2 \mathrm{H}) ; 7.17(\mathrm{~d}, 1 \mathrm{H}) ; 6.95(\mathrm{t}, 1 \mathrm{H}) ; 6.35$ $(\mathrm{t}, 1 \mathrm{H}) ; 6.26(\mathrm{~s}, 1 \mathrm{H}) ; 4.01(\mathrm{~s}, 2 \mathrm{H}) .{ }^{13} \mathrm{C}$ NMR $\left(\mathrm{d}_{6}\right.$-DMSO, $\left.\delta / \mathrm{ppm}\right): 172.17$ (COO); $167.23(C N) ; 148.89,138.69,135.02,132.61,128.51,126.88$, $125.03,122.68,119.67$ ( $C$ aromatic); $58.65\left(\mathrm{CH}_{2}\right)$. UV-Vis in DMSO, $\lambda_{\text {max }} / \mathrm{nm}\left(\varepsilon / \mathrm{M}^{-1} \mathrm{~cm}^{-1}\right): 266\left(3.2 \times 10^{4}\right), 371\left(6.3 \times 10^{3}\right)$. FTIR $(\mathrm{KBr}$, $\left.\mathrm{cm}^{-1}\right)$ : $1386\left(\nu_{s}, \mathrm{COO}\right), 1580\left(\nu_{\text {as, }} \mathrm{COO}\right), 1636(\nu, \mathrm{C}=\mathrm{N})$.

[Zn(Sal-Gly)(Clphen)( $\left.\mathbf{H}_{2} \mathbf{O}\right)$ ] 2. Yield: $79 \%$. Elemental Anal. Calc. for $\mathrm{C}_{21} \mathrm{H}_{16} \mathrm{~N}_{3} \mathrm{O}_{4} \mathrm{ClZn:} \mathrm{C}, 53.08 ; \mathrm{H}, 3.39 ; \mathrm{N}, 8.84$. Found: $\mathrm{C}, 52.75 ; \mathrm{H}$, 3.43; N, 8.49. ESI MS $m / z$ : [Calculated (Found)]: 456.00 (456.11) $(20 \%)[\mathrm{Zn}(\mathrm{Sal}-\mathrm{Gly})(\mathrm{Clphen})+\mathrm{H}]{ }^{+} .{ }^{1} \mathrm{H}$ NMR $\left(d_{\sigma}\right.$ DMSO, $\left.\delta / \mathrm{ppm}\right): 9.05$ $(\mathrm{dd}, 2 \mathrm{H}) ; 8.88(\mathrm{~d}, 1 \mathrm{H}) ; 8.70(\mathrm{~d}, 1 \mathrm{H}) ; 8.51(\mathrm{~s}, 1 \mathrm{H}) ; 8.45(\mathrm{~s}, 1 \mathrm{H}), 8.07(\mathrm{~m}$, 


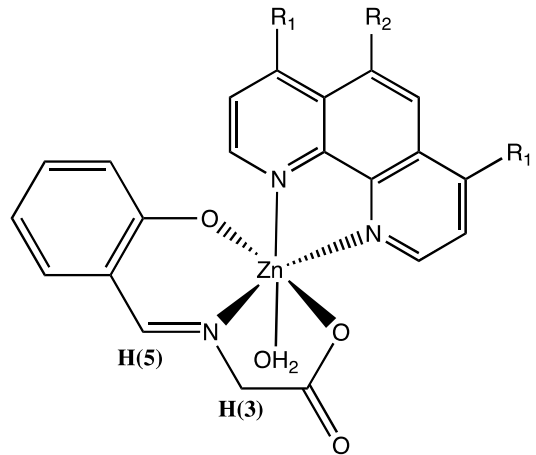

[Zn(Sal-Gly)(phen)( $\left.\left.\mathrm{H}_{2} \mathrm{O}\right)\right]$ 1: $\mathrm{R}_{1}=\mathrm{R}_{2}=\mathrm{H}$

[Zn(Sal-Gly)(Clphen)(H $\left.\left.\mathrm{H}_{2} \mathrm{O}\right)\right]$ 2: $\mathrm{R}_{1}=\mathrm{H} \mathrm{R}_{2}=\mathrm{Cl}$

[Zn(Sal-Gly)(amphen)( $\left.\left.\mathbf{H}_{2} \mathbf{O}\right)\right]$ 3: $\mathrm{R}_{1}=\mathrm{H} \mathrm{R}_{2}=\mathrm{NH}_{2}$

[Zn(Sal-Gly)(epoxyphen)(H $\left.\left.\mathbf{H}_{2} \mathrm{O}\right)\right]$ 4: $\mathrm{R}_{1}=\mathrm{H} \mathrm{R}_{2}=-\mathrm{O}$ - (epoxy)

[Zn(Sal-Gly)(Bphen) $\left.\left(\mathbf{H}_{2} \mathrm{O}\right)\right]$ 5: $\mathrm{R}_{1}=$ phenyl $\mathrm{R}_{2}=\mathrm{H}$

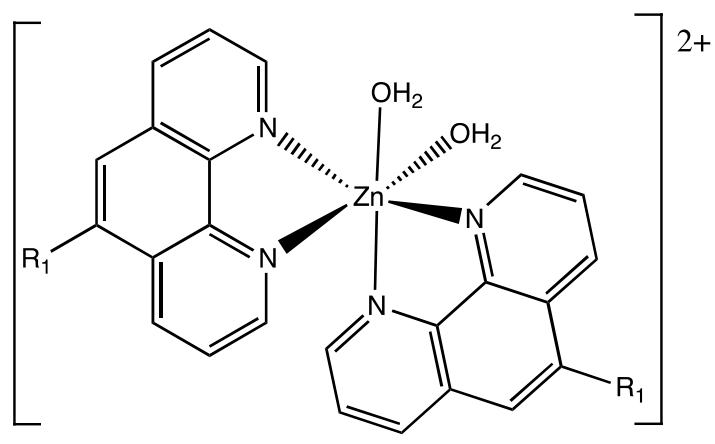

$\left[\mathrm{Zn}(\text { phen })_{2}\left(\mathrm{H}_{2} \mathrm{O}\right)_{2}\right]^{2+}$ 6: $\mathrm{R}_{1}=\mathrm{H}$ $\left[\mathrm{Zn}(\text { amphen })_{2}\left(\mathrm{H}_{2} \mathrm{O}\right)_{2}\right]^{2+}$ 7: $\mathrm{R}_{1}=\mathrm{NH}_{2}$

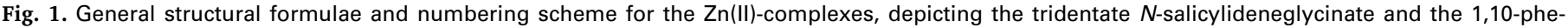
nanthroline-derived ligands. The labeling of protons 3 and 5 in complexes 1-5 are also indicated.

$1 \mathrm{H}) ; 7.96(\mathrm{~m}, 1 \mathrm{H}), 7.16(\mathrm{~m}, 1 \mathrm{H}), 6.98(\mathrm{t}, 1 \mathrm{H}) ; 6.35(\mathrm{t}, 2 \mathrm{H}), 4.00(\mathrm{~s}, 2 \mathrm{H})$. ${ }^{13} \mathrm{C}$ NMR (d - -DMSO, $\left.\delta / \mathrm{ppm}\right): 172.18(\mathrm{COO}) ; 167.34(\mathrm{CN}) ; 149.78$, $149.50,134.98,132.64,129.08,128.27,126.34,122.60,119.52$ ( $C$ aromatic); $58.43\left(\mathrm{CH}_{2}\right)$. UV-Vis in DMSO, $\lambda_{\text {max }} / \mathrm{nm}\left(\varepsilon / \mathrm{M}^{-1} \mathrm{~cm}^{-1}\right)$ : $268\left(3.7 \times 10^{4}\right), 374\left(6.8 \times 10^{3}\right)$. FTIR $\left(\mathrm{KBr}, \mathrm{cm}^{-1}\right): 1385\left(\nu_{s}, \mathrm{COO}\right)$, $1601\left(\nu_{\text {as }}, \mathrm{COO}\right), 1644(\nu, \mathrm{C}=\mathrm{N})$.

[Zn(Sal-Gly)(amphen)( $\left.\mathrm{H}_{2} \mathbf{O}\right)$ ] 3. Yield: $74 \%$. Elemental Anal. Calc. for $\mathrm{C}_{21} \mathrm{H}_{18} \mathrm{~N}_{4} \mathrm{O}_{4} \mathrm{Zn} \cdot 0.3 \mathrm{H}_{2} \mathrm{O}: \mathrm{C}, 54.69 ; \mathrm{H}, 4.06 ; \mathrm{N}, 12.15$. Found: $\mathrm{C}$, 54.75; H, 3.89; N, 11.95. ESI MS $m / z$ : [Calculated (Found)]: 437.05 (437.08) (30\%) [Zn(Sal-Gly)(amphen) $+\mathrm{H}]{ }^{+} .{ }^{1} \mathrm{H}$ NMR $\left(d_{\sigma}\right.$ DMSO, $\delta /$ ppm): 8.95 (d, 2H); $8.59(\mathrm{~d}, 1 \mathrm{H}) ; 8.54(\mathrm{~s}, 1 \mathrm{H}) ; 8.35(\mathrm{~d}, 1 \mathrm{H}) ; 7.96(\mathrm{t}, 1 \mathrm{H})$; $7.73(\mathrm{t}, 1 \mathrm{H}) ; 7.17(\mathrm{~d}, 1 \mathrm{H}) ; 7.00(\mathrm{~s}, 1 \mathrm{H}) ; 6.94(\mathrm{t}, 1 \mathrm{H}) ; 6.61(\mathrm{~s}, 2 \mathrm{H}) ; 6.32(\mathrm{t}$, $1 \mathrm{H}) ; 6.20(\mathrm{~d}, 1 \mathrm{H}) ; 4.03(\mathrm{~s}, 2 \mathrm{H}) .{ }^{13} \mathrm{C}$ NMR $\left(\mathrm{d}_{6}\right.$-DMSO, $\left.\delta / \mathrm{ppm}\right): 172.14$ (COO); 167.14 (CN); 148.25, 143.50, 143.37, 134.98, 133.78, 132.57, $131.03,124.88,123.73,122.67,121.85,119.72,111.50,100.85$ (C aromatic); $58.88\left(\mathrm{CH}_{2}\right)$. UV-Vis in DMSO, $\lambda_{\max } / \mathrm{nm}\left(\varepsilon / \mathrm{M}^{-1} \mathrm{~cm}^{-1}\right)$ : $277\left(1.9 \times 10^{4}\right), 361\left(9.9 \times 10^{3}\right)$. FTIR $\left(\mathrm{KBr}, \mathrm{cm}^{-1}\right): 1388\left(\nu_{s}, \mathrm{COO}\right)$, $1599\left(\nu_{\text {as }}, \mathrm{COO}\right), 1637(\nu, \mathrm{C}=\mathrm{N})$.

[Zn(Sal-Gly)(epoxyphen)( $\left.\left.\mathrm{H}_{2} \mathrm{O}\right)\right]$ 4. Yield: $90 \%$. Elemental Anal. Calc. for $\mathrm{C}_{21} \mathrm{H}_{17} \mathrm{~N}_{3} \mathrm{O}_{5} \mathrm{Zn} \cdot 0.8 \mathrm{H}_{2} \mathrm{O}: \mathrm{C}, 53.53 ; \mathrm{H}, 3.98 ; \mathrm{N}, 8.92$. Found: $\mathrm{C}, 53.57 ; \mathrm{H}, 3.84 ; \mathrm{N}, 8.87$. ESI MS $\mathrm{m} / z$ : [Calculated (Found)]: 438.04 (438.11) (15\%) [Zn(Sal-Gly)(epoxyphen) $+\mathrm{H}]{ }^{+} .{ }^{1} \mathrm{H}$ NMR $\left(d_{\sigma}\right.$ DMSO, $\delta / \mathrm{ppm}): 8.69(\mathrm{~d}, 2 \mathrm{H}) ; 8.53(\mathrm{~d}, 2 \mathrm{H}) ; 8.48(\mathrm{~s}, 1 \mathrm{H}) ; 7.73(\mathrm{~m}, 2 \mathrm{H}) ; 7.14(\mathrm{~d}$, $1 \mathrm{H}) ; 6.97(\mathrm{t}, 1 \mathrm{H}) ; 6.34(\mathrm{t}, 1 \mathrm{H}) ; 6.30(\mathrm{~s}, 1 \mathrm{H}) ; 4.97(\mathrm{~s}, 2 \mathrm{H}) ; 3.93(\mathrm{~s}, 2 \mathrm{H})$. ${ }^{13} \mathrm{C}$ NMR ( $\mathrm{d}_{6}$-DMSO, $\left.\delta / \mathrm{ppm}\right): 172.09$ (COO); 167.21 (CN); 148.61, 134.97, 132.61, 130.65, 126.17, 122.74, 119.61, 111.65 ( $C$ aromatic); $58.50\left(\mathrm{CH}_{2}\right) ; 53.90(\mathrm{CH})$. UV-Vis in DMSO, $\lambda_{\max } / \mathrm{nm}\left(\varepsilon / \mathrm{M}^{-1} \mathrm{~cm}^{-1}\right)$ : $300\left(1.3 \times 10^{4}\right), 371\left(6.9 \times 10^{3}\right)$. FTIR $\left(\mathrm{KBr}, \mathrm{cm}^{-1}\right): 1384\left(\nu_{s}, \mathrm{COO}\right)$, 1584 ( $\left.\nu_{\text {as, }} \mathrm{COO}\right), 1639(\nu, \mathrm{C}=\mathrm{N})$.

[Zn(Sal-Gly)(Bphen)( $\left.\mathbf{H}_{2} \mathbf{O}\right)$ ] 5. Yield: $80 \%$. Elemental Anal. Calc. for $\mathrm{C}_{33} \mathrm{H}_{25} \mathrm{~N}_{3} \mathrm{O}_{4} \mathrm{Zn} \cdot 0.5 \mathrm{H}_{2} \mathrm{O}: \mathrm{C}, 65.84 ; \mathrm{H}, 4.35 ; \mathrm{N}, 6.98$. Found: $\mathrm{C}$, 66.16; H, 4.32; N, 6.77. ESI MS $\mathrm{m} / \mathrm{z}$ : [Calculated (Found)]: 574.10 (574.11) (30\%) [Zn(Sal-Gly)(Bphen) $+\mathrm{H}]^{+}{ }^{1}{ }^{1} \mathrm{H} \mathrm{NMR}\left(\mathrm{CD}_{2} \mathrm{Cl}_{2}, \delta / \mathrm{ppm}\right)$ : $8.83(\mathrm{~d}, 2 \mathrm{H}) ; 8.47(\mathrm{~s}, 1 \mathrm{H}) ; 7.98(\mathrm{~s}, 2 \mathrm{H}) ; 7.52(\mathrm{~m}, 6 \mathrm{H}) ; 7.40(\mathrm{~m}, 6 \mathrm{H}) ; 7.28$ $(\mathrm{d}, 1 \mathrm{H}) ; 7.20(\mathrm{t}, 1 \mathrm{H}) ; 6.82(\mathrm{~d}, 1 \mathrm{H}) ; 6.71(\mathrm{t}, 1 \mathrm{H}) ; 3.61(\mathrm{~s}, 2 \mathrm{H}) .{ }^{13} \mathrm{C} N M R$ $\left(\mathrm{CD}_{2} \mathrm{Cl}_{2}, \delta / \mathrm{ppm}\right): 173.86$ (COO); $167.54(\mathrm{CN}) ; 151.79,148.68,136.81$, 135.19, 133.89, 130.13, 129.88, 129.45, 127.44, 125.51, 125.19, 115.77 ( $C$ aromatic); $60.44\left(\mathrm{CH}_{2}\right)$. UV-Vis in $\mathrm{EtOH}, \lambda_{\text {max }} / \mathrm{nm}(\varepsilon /$ $\left.\mathrm{M}^{-1} \mathrm{~cm}^{-1}\right): 222\left(5.4 \times 10^{4}\right), 279\left(4.7 \times 10^{4}\right), 358\left(6.0 \times 10^{3}\right)$. FTIR $\left(\mathrm{KBr}, \mathrm{cm}^{-1}\right)$ : $1389\left(\nu_{\mathrm{s}}, \mathrm{COO}\right), 1597\left(\nu_{\text {as, }} \mathrm{COO}\right), 1644(\nu, \mathrm{C}=\mathrm{N})$.

\subsection{2. $\left[\mathrm{Zn}(\mathrm{NN})_{2}\left(\mathrm{H}_{2} \mathrm{O}\right)_{2}\right]^{2+}$ complexes}

The homoleptic zinc complexes with polypyridyls were synthesized following procedures reported in the literature for similar compounds $[34,35]$. The polypyridyl $(1 \mathrm{mmol})$ was dissolved in ethanol (or methanol, $1 \mathrm{~mL}$ ) and added dropwise to a stirred ethanolic solution $(1.5 \mathrm{~mL})$ of $\mathrm{Zn}\left(\mathrm{NO}_{3}\right)_{2} \cdot 4 \mathrm{H}_{2} \mathrm{O}(130.7 \mathrm{mg}, 0.5 \mathrm{mmol})$. The mixture was stirred for $2 \mathrm{~h}$ at room temperature or under reflux and left overnight at $4{ }^{\circ} \mathrm{C}$. The solid was collected by filtration, washed with small amounts of cold water, acetone and ethyl ether and dried over silica gel under vacuum.

$\left[\mathrm{Zn}(\text { phen })_{2}\left(\mathrm{H}_{2} \mathrm{O}\right)_{2}\right]\left(\mathrm{NO}_{3}\right)_{2}$ 6. A white solid was obtained. Yield: $176 \mathrm{mg}, 64.0 \%$. Elemental analysis for $\mathrm{C}_{24} \mathrm{H}_{20} \mathrm{~N}_{6} \mathrm{O}_{8} \mathrm{Zn}$ : C, $49.20 \%$; H, 3.44\%; N, 14.35\%. Found: C, 48.86\%; H, 3.11\%; N, 14.12\%. ESIMS (MeOH) $\mathrm{m} / \mathrm{z}$ [Calculated (Found)]: 486.04 (486.04) (90\%) [Zn $\left.(\text { phen })_{2}\left(\mathrm{NO}_{3}\right)\right]^{+} \quad\left(\mathrm{C}_{24} \mathrm{H}_{16} \mathrm{~N}_{5} \mathrm{O}_{3} \mathrm{Zn}\right) ; \quad 212.3 \quad(212.0) \quad(14 \%) \quad[\mathrm{Zn}$ (phen) $\left.)_{2}\right]^{2+}\left(\mathrm{C}_{12} \mathrm{H}_{8} \mathrm{~N}_{2} \mathrm{Zn}_{0.5}\right)$. ${ }^{1} \mathrm{H}$ NMR (MeOD-d4, $\left.\delta / \mathrm{ppm}\right): 8.98$ (d, $4 \mathrm{H}, \mathrm{H}^{1}$ and $\left.\mathrm{H}^{11}\right), 8.75\left(\mathrm{~s}, 4 \mathrm{H}, \mathrm{H}^{5}\right.$ and $\left.\mathrm{H}^{13}, \mathrm{br}\right), 8.36\left(\mathrm{~s}, 4 \mathrm{H}, \mathrm{H}^{7}\right.$ and $\left.\mathrm{H}^{8}\right)$, $8.08\left(\mathrm{~s}, 4 \mathrm{H}, \mathrm{H}^{6}\right.$ and $\mathrm{H}^{12}$, br). ${ }^{13} \mathrm{C}$ NMR (MeOD-d4, $\left.\delta / \mathrm{ppm}\right): 149.1\left(\mathrm{C}^{5}\right.$ and $\left.C^{13}\right), 140.5\left(C^{1}\right.$ and $\left.C^{11}\right), 139.7\left(C^{3}\right.$ and $\left.C^{10}\right), 129.0\left(C^{2}\right.$ and $\left.C^{9}\right)$, $128.0\left(C^{7}\right.$ and $\left.C^{8}\right), 126.6\left(C^{6}\right.$ and $\left.C^{12}\right)$. UV-Vis in DMSO, $\lambda_{\text {max }} / \mathrm{nm}(\varepsilon /$ $\left.\mathrm{M}^{-1} \mathrm{~cm}^{-1}\right): 325\left(1.17 \times 10^{3}\right), 294\left(1.28 \times 10^{4}\right), 272\left(3.59 \times 10^{4}\right), 267$ $\left(3.76 \times 10^{4}\right)$. FTIR $\left(\mathrm{KBr}, \mathrm{cm}^{-1}\right)$ : $1620(\nu, \mathrm{C}=\mathrm{N}), 1579(\nu, \mathrm{C}=\mathrm{C})$.

[ $\mathrm{Zn}$ (amphen $\left.)_{2}\left(\mathrm{H}_{2} \mathrm{O}\right)_{2}\right]\left(\mathrm{NO}_{3}\right)_{2}$ 7. A yellow solid was obtained. (Yield: $236 \mathrm{mg}, 81.4 \%$ ). Elemental analysis for $\mathrm{C}_{24} \mathrm{H}_{22} \mathrm{~N}_{8} \mathrm{O}_{8} \mathrm{Zn:} \mathrm{C}$, 47.81\%; H, 3.60\%; N, 18.19\%. Found: 47.51\%; H, 3.18\%; N, $18.43 \%$. ESI-MS (MeOH) m/z [Calculated (Found)]: 516.10 (516.10) (10\%) [Zn (amphen) $\left.{ }_{2}\left(\mathrm{NO}_{3}\right)\right]^{+}\left(\mathrm{C}_{24} \mathrm{H}_{18} \mathrm{~N}_{7} \mathrm{O}_{3} \mathrm{Zn}\right) ; 227.00$ (227.3) (100\%) [Zn (amphen) $\left.{ }_{2}\right]^{2+}\left(\mathrm{C}_{12} \mathrm{H}_{9} \mathrm{~N}_{3} \mathrm{Zn}_{0.5}\right)$. ${ }^{1} \mathrm{H}$ NMR (Methanol- $d_{4}, \delta / \mathrm{ppm}$ ): 7.15-9.1 (aromatic-Hs). ${ }^{13} \mathrm{C}$ NMR (Methanol- $d_{4}, \delta / \mathrm{ppm}$ ): 103.35-149.38 (aromatic-Cs). UV-Vis in DMSO, $\lambda_{\text {max }} / \mathrm{nm}(\varepsilon /$ $\left.\mathrm{M}^{-1} \mathrm{~cm}^{-1}\right): 363\left(1.86 \times 10^{4}\right), 298\left(5.19 \times 10^{4}\right), 268\left(4.42 \times 10^{4}\right)$. FTIR $\left(\mathrm{KBr}, \mathrm{cm}^{-1}\right): 1615(\nu, \mathrm{C}=\mathrm{N}), 1593(\nu, \mathrm{C}=\mathrm{C})$.

From this point further the water molecules and $\mathrm{NO}_{3}{ }^{-}$ions included in the solid complex formulation will be omitted for simplicity, unless relevant. Also, sometimes the complexes will be referred to as $\mathrm{Zn}$ (phen) ${ }_{2}$ and $\mathrm{Zn}(\text { amphen })_{2}$, not specifying charges.

\subsection{General procedures for X-ray crystallography}

Crystals suitable for single-crystal X-ray analysis were obtained for a compound designated as $\mathbf{5}$ a from the slow evaporation of an ethanolic solution of $\mathbf{5}$. The data were collected using a graphite monochromated Mo-K $\alpha$ radiation $(\lambda=0.71073 \AA$ ) on a Bruker AXSKAPPA APEX II diffractometer equipped with an Oxford Cryo system open-flow nitrogen cryostat. Cell parameters were retrieved using Bruker SMART software and refined using Bruker SAINT on all observed reflections. Absorption corrections were 
applied using SADABS [36]. The structures were solved using direct methods with program SIR2004 [37] and refined with program SHELXL [38], included in the WINGX-Version 2014.1 [39] system of programs. All non-hydrogen atoms were refined anisotropically and the hydrogen atoms were inserted in idealised positions and allowed to refine riding on the parent carbon atom. SQUEEZE [40] was used for the final refinement due to the presence of disordered solvent molecules. The electron density modelled by SQUEEZE is consistent with about 14 ethanol molecules per unit cell (ca. 279 electrons for a volume of ca. $847 \AA^{3}$ ), corresponding to about 7 ethanol molecules per molecule of $\mathbf{5 a}$. The molecular diagrams were drawn with ORTEP-3 for Windows [41] included in the software package.

Crystal Data for $\mathrm{C}_{66} \mathrm{H}_{46} \mathrm{~N}_{6} \mathrm{O}_{6} \mathrm{Zn}_{2}(\mathrm{M}=1149.83 \mathrm{~g} / \mathrm{mol})$ : triclinic, space group P-1, $a=13.1470(5) \AA, b=14.2290(6) \AA, c=20.0460(9) \AA$, $\alpha=110.681(2)^{\circ}, \beta=93.023(2)^{\circ}, \gamma=110.093(2)^{\circ}, V=3229.5(2) \AA^{3}, Z=2$, $T=150(2) \mathrm{K}, \mu(\mathrm{MoK} \alpha)=0.794 \mathrm{~mm}^{-1}, 32,134$ reflections measured, 13,174 unique $\left(R_{\text {int }}=0.0449, R_{\text {sigma }}=0.0672\right)$ which were used in all calculations. The final $R_{1}$ was $0.0376(I>2 \sigma(I))$ and $w R_{2}$ was 0.0939 (all data).

For more crystallographic experimental data and structure refinement parameters see Tables S1-S3 in Supplementary Information (SI). CCDC 1840672 contains the supplementary crystallographic data for this work. The data can be obtained free of charge from The Cambridge Crystallographic Data Centre via www.ccdc.cam.ac.uk/structures.

\subsection{Stability studies in aqueous medium}

Stock solutions of the $\left[\mathrm{Zn}(\mathrm{Sal}-\mathrm{Gly})(\mathrm{NN})\left(\mathrm{H}_{2} \mathrm{O}\right)\right]$ complexes were prepared in DMSO with ca. $1 \mathrm{mM}$. 1:20 dilutions were then prepared in PBS buffer ( $\mathrm{pH} 7.4)$, having a final complex concentration of ca. $50 \mu \mathrm{M}$ and $5 \%$ DMSO. The UV-Visible spectra $(230-500 \mathrm{~nm})$ were recorded for a few hours ( 3 to $19 \mathrm{~h}$ ). Another spectrum was recorded after $24 \mathrm{~h}$.

For the $\left[\mathrm{Zn}(\mathrm{NN})_{2}\right]^{2+}$ complexes several techniques were used. In the UV-Vis absorption study, $1.0 \mathrm{mM}$ of $\mathbf{6}$ or $\mathbf{7}$ stock solutions of the complexes were prepared in DMSO. 1:20 dilutions were done in PBS buffer ( $\mathrm{pH} 7.4)$, having final metal concentrations of $50 \mu \mathrm{M}$. UV-Visible absorption spectra $(260-500 \mathrm{~nm})$ were recorded for up to $24 \mathrm{~h}$. Similarly, for the fluorescence studies, stock solutions of the complexes with concentrations of $500 \mu \mathrm{M}$ were prepared in DMSO. Dilution in PBS yielded solutions with $25 \mu \mathrm{M}$ concentration. The fluorescence emission spectra were recorded at 3 and $24 \mathrm{~h}$, using excitation wavelengths of 326 and $450 \mathrm{~nm}$, for 6 and 7, respectively.

An additional stability study was carried out for $\mathbf{6}$. A phosphate buffer solution ( $120 \mathrm{mM}$ and $\mathrm{pH}$ 7.5) was prepared by dissolving $2.4 \mathrm{mg} \mathrm{KH_{2 }} \mathrm{PO}_{4}$ and $14.4 \mathrm{mg} \mathrm{Na} \mathrm{HPO}_{4}$ in $1 \mathrm{~mL}$ of $\mathrm{D}_{2} \mathrm{O}$. $12.5 \mathrm{mg}$ of the complex were dissolved in $250 \mu \mathrm{L}$ of DMSO- $d_{6}$. Then, $20 \mu \mathrm{L}$ of this solution were mixed with $380 \mu \mathrm{L}$ of the phosphate buffer giving $5 \%$ DMSO and $95 \%$ deuterated PBS. The stability of the compound was evaluated for $24 \mathrm{~h}$ by ${ }^{1} \mathrm{H}$ NMR spectroscopy.

\subsection{Cell studies}

\subsubsection{Solutions and cellular media}

Cells were cultured in RPMI-1640 (A2780) or DMEM+Glutamax-I (MCF7, HeLa, V79) supplemented with $10 \%$ fetal bovine serum (FBS) and $1 \%$ antibiotics in a $5 \% \mathrm{CO}_{2}$ incubator (Heraus, Germany) at $37^{\circ} \mathrm{C}$ and in a humidified atmosphere.

\subsubsection{Cytotoxicity (MTT assay)}

The cytotoxicity of the complexes was assessed against $A 2780$, MCF7, HeLa and V79 cells by the MTT assay (MTT $=3-(4,5-\mathrm{di}-$ methylthiazol-2-yl)-2,5-diphenyltetrazolium bromide) using 96-well plates. The compounds were first dissolved in DMSO and then in medium through serial dilutions ranging from $0.01 \mu \mathrm{M}$ to $100 \mu \mathrm{M}$. The final DMSO concentration did not exceed $1 \%(\mathrm{v} / \mathrm{v})$ in either control or treated cells and, under these conditions, it had no effect on the cellular activity.

For the studies of the effect of FBS on the cytotoxic activity, A2780 cells were incubated in media containing different concentrations of serum from 1 to $20 \%$ and the complex at a concentration equivalent to its $\mathrm{IC}_{50}$ found at 24 and $48 \mathrm{~h}$. Controls (no treatment) for each concentration of FBS were included in the assays.

After treatment with the complexes the cell medium was replaced by $200 \mu \mathrm{L}(0.5 \mathrm{mg} / \mathrm{mL})$ of a MTT solution in PBS and further incubated for $3 \mathrm{~h}$ at $37^{\circ} \mathrm{C}$. The resulting purple formazan crystals from the tetrazolium reduction were solubilized in DMSO. Absorbance in controls and cell-treated wells was measured at $575 \mathrm{~nm}$ using a microplate reader (PowerWave Xs, Biotek Instruments, USA). The cytotoxicity of the complexes was expressed as the $\mathrm{IC}_{50}$ calculated from dose-response curves using the GraphPad Prism software (vs. 5.0).

\subsubsection{Generation of superoxide radicals (NBT assay)}

The nitro blue tetrazolium (NBT) assay [NBT $=2,2^{\prime}$-bis(4Nitrophenyl)-5,5'-diphenyl-3,3'-(3,3'-dimethoxy-4,4'-diphenylene) ditetrazolium) chloride] was carried out adapting previously described methods using the 96-well plates model [42-44]. After a pretreatment with the ligands and corresponding complexes at 1, 10 and $100 \mu \mathrm{M}$ for $1 \mathrm{~h}$ at $37^{\circ} \mathrm{C}, 20 \mu \mathrm{L}$ of a NBT solution $10 \mathrm{mg} / \mathrm{mL}$ in water was added to the medium of the treated cells (A2780) and incubation was subsequently carried out for $1 \mathrm{~h}$ at $37^{\circ} \mathrm{C}$. The culture medium was then gently poured and the blue formazan particles were dissolved in $200 \mu \mathrm{L}$ of $90 \%$ DMSO (90\% DMSO:10\% $\mathrm{NaOH} 0.1 \mathrm{~N}$ with $0.1 \% \mathrm{SDS}$ ). NBT is reduced by superoxide radical anion to NBT formazan, which is spectrophotometrically measured at $560 \mathrm{~nm}$. Each experiment was repeated twice and each concentration was tested with at least six replicates. Results (mean \pm $\mathrm{SD}$ ) are expressed as \% of controls (untreated cells).

\subsubsection{Apoptosis (caspase $3 / 7$ assay)}

Apoptosis was assessed using the Caspase-Glo ${ }^{\circledast}$ 3/7 Assay (Promega), according to manufacturer's instructions. With this luminescent assay activities of caspase- 3 and caspase-7, both involved in apoptotic caspase, were measured. The assay provides a proluminogenic caspase $3 / 7$ substrate containing the tetrapeptide sequence Asp-Glu-Val-Asp (DEVD aminoluciferin). In the presence of caspase $3 / 7$ this substrate is cleaved; aminoluciferin is released, consumed by luciferase (provided in the reaction mixture), which generates a luminescent signal. The luminescent signal is proportional to the caspase activity present in the cells. The assay was carried out in A2780 cells, plated in 96 wells, treated with the free ligands and compounds $\mathbf{1 - 5}$ for $48 \mathrm{~h}$ at concentrations equivalent to their $\mathrm{IC}_{50}$. After $48 \mathrm{~h}, 100 \mu \mathrm{L}$ of medium was removed from each well. Caspase $3 / 7^{\circledR}$ reagent was added in a $1: 1$ ratio and the plate was shaken in an orbital shaker for $30 \mathrm{~s}$ at $300-500 \mathrm{rpm}$. The plate was incubated at room temperature, protected from light for $1.5 \mathrm{~h}$. The luminescence intensity was measured using an Infinite 200 Plate Reader (Tecan). Each experiment was repeated twice and each concentration was tested with at least three replicates. Results (mean $\pm \mathrm{SD}$ ) were expressed as RLU (relative luminescent units).

\subsubsection{Cellular uptake by inductively coupled plasma mass spectrometry (ICP-MS)}

To measure the cellular uptake and distribution of 1, 3 and 6 , approx. 1 million A2780 cells were incubated with the complexes in cell culture medium at a concentration equivalent to the $\mathrm{IC}_{50}$ values found at $24 \mathrm{~h}$ incubation. After incubation at $37^{\circ} \mathrm{C}$ the cellular 
pellet obtained was treated with a cell fractionation system (FractionPREP ${ }^{\mathrm{TM}}$, Biovision) to extract cytosolic, membranes/particulate, nuclear and cystoskeletal fractions. These fractions were dissolved with $0.5 \mathrm{~mL}$ nitric acid $(65 \%)$ with a hot plate at $100{ }^{\circ} \mathrm{C}$ during $12 \mathrm{~h}$. The solution digest is diluted in ultrapure water to $10 \mathrm{~mL}$, obtained from a MilliQ apparatus. The $\mathrm{Zn}$ content $\left({ }^{66} \mathrm{Zn}\right)$ was measured by a Thermo X-Series Quadrupole ICP-MS (Thermo Scientific) equipped with $\mathrm{Ni}$ cones and a glass concentric nebulizer (Meinhard, $1.0 \mathrm{~mL} \mathrm{~min}{ }^{-1}$ ) refrigerated with a Peltier system. Indium $\left({ }^{115} \mathrm{In}\right)$ at a concentration of $10 \mu \mathrm{g} \mathrm{L}^{-1}$ was used as internal standard. Standards were prepared from standard ICP-MS $71 \mathrm{~A}$ (Inorganic Venture) with a final concentration of $5.0 \%$ nitric acid. The following quality control was applied: internal standard accepted variation between 80 and 120\%; blank's concentrations inferior to the limit of detection $\left(1 \mu \mathrm{g} \mathrm{L}^{-1}\right)$ and sample duplicates do not differ $>10 \%$. The $\mathrm{Zn}$ levels in each fraction were expressed as ng metal content/million A2780 cells.

\subsubsection{Morphological analysis by transmission electron microscopy (TEM)}

A2780 cells at approx. $70 \%$ confluence were treated with two $\mathrm{Zn}$ (II) complexes, $\mathbf{1}$ and $\mathbf{3}$ at concentrations equivalent to their $\mathrm{IC}_{50}$ values found at $24 \mathrm{~h}$ incubation. Non-treated cells were used as controls. After incubation, cells were processed following a standard procedure previously reported [45]. Briefly, the culture medium was discarded and replaced by a primary fixative consisting in sodium cacodylate buffer $0.1 \mathrm{M}, \mathrm{pH} 7.3$ containing $3 \%$ glutaraldehyde. After primary fixation for $2 \mathrm{~h}$ at $4{ }^{\circ} \mathrm{C}$ and a wash step in cacodylate buffer, cells were then scraped, pelleted and embedded in $2 \%$ agar. Samples were then further fixed for $3 \mathrm{~h}$ in sodium cacodylate buffer $0.1 \mathrm{M}, \mathrm{pH} 7.3$ containing $1 \%$ osmium tetroxide. Next, samples were washed in acetate buffer $(0.1 \mathrm{M}$, $\mathrm{pH}=5.0$ ) and fixed in $0.5 \%$ uranyl acetate in the same buffer for $1 \mathrm{~h}$. Dehydration was carried out with increasing concentrations of ethanol. After passing through propylene oxide, samples were embedded in Epon-Araldite, using SPI-Pon as an Epon 812 substitute. Glass or diamond knives were used to cut thin sections, which were stained with $2 \%$ aqueous uranyl acetate and Reynold's lead citrate. The stained sections were analyzed and photographed in a JEOL 1200-EX electron microscope.

\subsubsection{Lipid peroxidation assay}

The content of malondialdehyde (MDA) and 4-hydroxynonenal (4-HNE) in lipid extracts of A2780 cells was measured using a colorimetric kit (BioVision, CA, USA). A2780 cells were seeded at $\sim 5 \times 10^{5}$ cells $/ 2 \mathrm{~mL}$ medium in 6 -well plates for $24 \mathrm{~h}$ to allow cells to adhere. Then, after treatment with the complexes at $10 \mu \mathrm{M}(\mathbf{1}, \mathbf{3}, 4$ and 5) and $50 \mu \mathrm{M}(2)$ for $24 \mathrm{~h}$ at $37^{\circ} \mathrm{C}$, the medium was removed, the cells were washed with PBS, tripsinized and centrifuged to obtain a pellet. After keeping an aliquot for determination of the number of cells per well, the pellet was treated following the kit manufacture's protocol. Briefly, the cells were lysed and centrifuged to remove insoluble materials and then, to $200 \mu \mathrm{L}$ of the supernatant, $600 \mu \mathrm{L}$ of thiobarbituric acid (TBA) was added to generate the MDA-TBA adduct which was developed incubating the mixture for $1 \mathrm{~h}$ at $95^{\circ} \mathrm{C}$. After reaction, $200 \mu \mathrm{L}$ were taken and transferred to a 96 -well plate for quantification at $532 \mathrm{~nm}$. To generate a MDA standard curve and in parallel with the samples, MDA standards were made using the same procedure. In the absence of cells, lipid peroxides were undetectable in the medium. Results were expressed as mean \pm SD from two separate experiments in which triplicate measurements were made.

\subsection{DNA binding studies}

Stock solutions of DNA were prepared by dissolving the nucleic acid in PBS or HEPES $10 \mathrm{mM}$ buffers (pH 7.4), kept at $4{ }^{\circ} \mathrm{C}$ for about $48 \mathrm{~h}$ and used within a week. Solutions of DNA gave ratios of absorbance $A_{260} / A_{280}$ of ca. 1.9, indicating that the DNA was sufficiently protein free $[46,47]$. The concentration of the prepared ctDNA stock solutions were calculated based on their absorbance at $260 \mathrm{~nm}$ by using the per nucleotide extinction coefficient $\varepsilon_{260}=6600 \mathrm{M}^{-1} \mathrm{~cm}^{-1}$ [47].

\subsubsection{UV-Vis absorption spectroscopy}

Electronic absorption titrations were done by adding aliquots of the DNA stock solution to solutions of the compounds in $3 \%$ DMSO-HEPES ( $10 \mathrm{mM}, \mathrm{pH}=7.4)$. The DNA solution was also added to the reference cell. Samples were allowed to equilibrate for a few minutes before recording each spectrum. The initial concentrations were the following: [phen] $=1.4 \times 10^{-5}$, [amphen] $=3.3 \times 10^{-5} \mathrm{M}$, $[6]=[7]=1.7 \times 10^{-5} \mathrm{M}$. The $[\mathrm{DNA}] /[$ Compound] ratio varied between 0 and 8.0. The data were fitted assuming the formation of a 1:1 association complex between DNA and the compounds (see section $\mathrm{SI} 4$ in $\mathrm{SI}$ ).

\subsubsection{Circular Dichroism spectroscopy}

Circular dichroism studies were done in quartz SUPRASIL ${ }^{\circledR}$ cuvettes of $10 \mathrm{~mm}$ optical path. The ctDNA solution was prepared by dilution of the stock solution in HEPES $10 \mathrm{mM}$ buffer to obtain concentrations of $c a .55-80 \mu \mathrm{M}$ in each sample, prior to addition of stock solutions of the Zn-complexes' or ligands in DMSO, $\mathrm{H}_{2} \mathrm{O}$ or $\mathrm{MeOH}$ (ca. 2.0-5.6 mM), to obtain each compound:DNA ratio. The samples were allowed to equilibrate for a few minutes before measurements. HEPES buffer or HEPES/DMSO mixtures were used to obtain the baseline, which was subtracted from each CD spectrum. The spectra were collected from 200 to $500 \mathrm{~nm}$ with a resolution of $1 \mathrm{~nm}$; band width of $1 \mathrm{~nm} ; 3$ accumulations; scan speed $200 \mathrm{~nm} / \mathrm{min}$ and $2 \mathrm{~s}$ response time.

\subsubsection{Fluorescence emission spectroscopy}

To solutions of the compounds (13.8 to $33 \mu \mathrm{M})$ in DMSO:HEPES buffer $(\mathrm{pH}=7.4$ ) (DMSO $0.4 \%$ to $1.2 \%, v / \mathrm{v})$, ctDNA $(1.5-2.0 \mathrm{mM})$ in HEPES was successively added directly to the cuvette, so that the DNA:complex molar ratio varied between 0.05 and 12 . Before each measurement the solutions were kept with gentle stirring for at least $5 \mathrm{~min}$ to equilibrate. The fluorescence emission spectra were recorded at room temperature using the excitation wavelengths of 295, 333, 297, and $338 \mathrm{~nm}$ (slits $=5 \mathrm{~nm}$ ) for phen, amphen, 6 and 7, resulting in emission maxima at $359,570,350$ and $588 \mathrm{~nm}$, respectively. The fluorescence emission intensities were corrected for the absorption and inner filter effects using UV-Visible absorption data recorded for each sample $[48,49]$. The fluorescence emission of the samples was recorded from 300 to $660 \mathrm{~nm}$ in a $10 \mathrm{~mm}$ quartz SUPRASIL ${ }^{\circledR}$ cuvette.

Fluorescence data were analyzed according to the Stern-Volmer equation to determine the fluorescence quenching and enhancement constant:

$\frac{I_{0}}{I}=1+K_{s v}[Q]$

$\frac{I_{0}}{I}=1+K_{s v}[E]$

where $I_{0}$ and $I$ are the fluorescence intensities in the absence and presence of DNA (Quencher $Q$ or enhancer E), respectively. SternVolmer quenching/enhancing constant, $\mathrm{K}_{\mathrm{SV}}$, are determined from the slope of the plot $\mathrm{I}_{\mathrm{O}} / \mathrm{l}$ versus [DNA].

\subsection{Bovine serum albumin (BSA) binding studies}

Concentrated stock solutions of BSA were prepared in buffer 
solution (HEPES with $10 \mathrm{mM}, \mathrm{pH} 7.4$ at $25^{\circ} \mathrm{C}$ ) and kept at $4{ }^{\circ} \mathrm{C}$ at least $3 \mathrm{~h}$ to hydrate. The concentration of the protein stock solutions was ca. $46 \mu \mathrm{M}$, estimated considering the molar extinction coefficient at $279 \mathrm{~nm}\left(44,309 \mathrm{M}^{-1} \mathrm{~cm}^{-1}\right)$ [50]. A stock solution of 1,10-phenanthroline was prepared by dissolving the compound in spectroscopic DMSO to obtain a final concentration of $550 \mu \mathrm{M}$.

The protein stock solution was diluted to the working concentration of ca. $2 \mu \mathrm{M}$ in HEPES buffer with a final volume of $3.0 \mathrm{~mL}$ placed in a quartz cuvette with a $1 \mathrm{~cm}$ path length. The tryptophan fluorescence quenching experiments were done by incremental additions of 2-67 $\mu \mathrm{L}$ of 1,10-phenanthroline stock solution to obtain final concentrations ranging from 0.4 to $29 \mu \mathrm{M}$ (DMSO $<5 \% \mathrm{v} / \mathrm{v}$ ). After each addition the solutions were equilibrated for ca. $5 \mathrm{~min}$ before the acquisition of spectra. The fluorescence emission spectra were recorded between 300 and $450 \mathrm{~nm}$ by applying an excitation wavelength of $295 \mathrm{~nm}$. UV-visible absorption spectra were recorded for each sample to correct the absorption and inner filter effects $[48,49]$ of the fluorescence emission intensities. Due to the intrinsic emission fluorescence of the quencher (1,10-phenanthroline), the fluorescence emission spectra of the ligand alone, under the same experimental conditions used in the BSA titration assays, were recorded and subtracted to each corresponding emission spectrum. The increasing concentrations of phen induce a decrease in the emission fluorescence intensity of BSA tryptophan residue $\left(\lambda_{\max }=343 \mathrm{~nm}\right)$ and the fluorescence quenching was fitted with the Stern-Volmer Eq. (1).

\section{Results and discussion}

A series of ternary $\mathrm{Zn}$ (II) complexes with the salycylaldimine $\mathrm{N}$ salicylidene-glycinate (Sal-Gly) as one of the ligands, and five different polypyridyls was synthesized in good yields by reaction of $\mathrm{Zn}$ (II) acetate with stoichiometric amounts of the tridentate Sal-Gly, generated in situ, and the co-ligand. Reaction of $\mathrm{Zn}$ (II) nitrate with 2 mol equivalents of selected polypyridyls at room temperature in methanol yielded $\left[\mathrm{Zn}(\mathrm{NN})_{2}\right]$-type complexes. Complexes 1 and 6 are not new, but were included here for comparison with the new compounds. The crystal structure of $\mathbf{1}$ was previously determined [51] showing a six coordinate Zn-center, with a water molecule completing the coordination sphere. For $\mathbf{6}$ several different crystal structures have been obtained [52,53] (a search in CSD database yielded 36 hits), all showing the $\mathrm{Zn}$ metal center with a coordination number of 6 . To the best of our knwoledge complexes 2-5 and 7 are new. The compounds were characterized in the solid state and in solution using analytical and spectroscopic techniques. Results obtained from elemental analysis, UV-Vis electronic absorption, ESI MS, FTIR and ${ }^{1} \mathrm{H}$ NMR spectroscopy (see below) are in agreement with the proposed formulations: [ $\mathrm{Zn}(\mathrm{Sal}-\mathrm{Gly})(\mathrm{NN})$ $\left.\left(\mathrm{H}_{2} \mathrm{O}\right)\right]\left(\mathrm{H}_{2} \mathrm{O}\right)_{x}$ and $\left[\mathrm{Zn}(\mathrm{NN})_{2}\left(\mathrm{H}_{2} \mathrm{O}\right)_{2}\right]\left(\mathrm{NO}_{3}\right)_{2}$. Their structural formulae are depicted in Fig. 1.

\subsection{FTIR spectroscopy}

Tentative assignments of the main FTIR bands were made based on previous reports $[51,54,55]$ and also on the vibrational behavior of vanadium and copper complexes of salicylaldimines $[18,20,56]$. The FTIR spectra obtained for the [Zn(Sal-Gly)(NN) $\left(\mathrm{H}_{2} \mathrm{O}\right)$ ] complexes display the presence of strong imine stretching bands $\nu(C=N)$ in the range of $1636-1644 \mathrm{~cm}^{-1}$, as predicted in the literature for the coordination of a Schiff base to a metal ion (Table S1 in Electronic Supplemental Information) [20,56-58]. A strong band found between 1580 and $1601 \mathrm{~cm}^{-1}$ is consistent with an asymmetric carboxylate stretch $\nu_{a s}(\mathrm{COO})$, the symmetric stretch, $\nu_{s}(\mathrm{COO})$, being observed between 1384 and $1389 \mathrm{~cm}^{-1}$. The difference between these two values (around $200 \mathrm{~cm}^{-1}$ ) is characteristic of monodentate coordination of the O-carboxylate atom
[56]. The phenolic $\nu\left(\mathbf{C}_{\mathbf{P h}}-\mathrm{O}\right)$ around $1300 \mathrm{~cm}^{-1}$, probably coupled to vibrations of the aromatic ring [58], was also identified. The presence of phenanthroline in the coordination sphere of the complexes was confirmed by several bands corresponding to stretching and deformation vibrations of the $\mathrm{N}$-heterocyclic ligands. Differences among vibrational spectra of the complexes were found, as expected due to electronic effects of the various phenanthroline ring substituents.

The FTIR spectra of the phen and amphen ligands show characteristic bands at 1636 and $1667 \mathrm{~cm}^{-1}$, respectively, associated with vibrations of the $-\mathrm{C}=\mathrm{N}-\mathrm{C}-$ moiety. In the FTIR spectra of the corresponding $\left[\mathrm{Zn}(\mathrm{NN})_{2}\left(\mathrm{H}_{2} \mathrm{O}\right)_{2}\right]^{2+}$ complexes, they were shifted, due to coordination through the nitrogen atoms.

\subsection{Electronic absorption spectroscopy}

Electronic spectral data for the $\mathrm{Zn}$-complexes in solution are given in Table S2. An absorption band in the range $355-375 \mathrm{~nm}$ was observed in the electronic spectra of the $\mathrm{Zn}$ (Sal-Gly)-complexes, which is attributed to $\pi \rightarrow \pi^{*}$ and $n \rightarrow \pi^{*}$ transitions originating mainly in the azomethine chromophore. The aromatic ring absorption bands from the coordinated phenanthroline ligands and benzene ring are observed in the UV region between 266 and $300 \mathrm{~nm}$ for all the complexes (including 6 and 7), and are due to $\pi \rightarrow \pi^{*}$ ring transitions $[57,59]$. These are in agreement with the observed for the same type of complexes with $\mathrm{Cu}$ (II) [19] and with $\mathrm{V}^{\mathrm{IV} \mathrm{O}}$ [60], which showed strong intraligand bands at 230-250 and at $270-300 \mathrm{~nm}$ and intense bands at $375-385 \mathrm{~nm}$.

\subsection{NMR spectroscopy}

The ${ }^{1} \mathrm{H}$ NMR spectra of $\mathbf{1 - 5}$ are somewhat diverse. When compared to the NN ligand precursors, all complexes' spectra show downfield shifts for the proton signals, consistent with coordination to the $\mathrm{Zn}$ (II) center. The aromatic protons belonging to the Sal-Gly benzene ring are observed in the range 7.3-6.2 ppm, upfield and in most cases in a clearly separate region of the spectra from the phenanthroline proton chemical shifts, which appear between 9.2 and $7.2 \mathrm{ppm}$. The azomethine proton $\mathrm{H}(5)$ (Fig. 1 and Table S3) appears as a singlet at $8.90-8.48 \mathrm{ppm}$. The $\mathrm{CH}_{2}$ protons adjacent to the carboxylate moiety $\mathrm{H}(3)$ are observed also as a singlet at $4.17-3.68 \mathrm{ppm}$. Characteristic signals associated with phenanthroline derivatives' structural features were also observed. Some examples are the $\mathrm{CH}-\mathrm{CH}$ proton signal recorded at $4.99 \mathrm{ppm}$ as a singlet in 4, or the $\mathrm{NH}_{2}$ singlet recorded at $6.61 \mathrm{ppm}$ in 3.

The homoleptic $\left[\mathrm{Zn}(\mathrm{NN})_{2}\left(\mathrm{H}_{2} \mathrm{O}\right)_{2}\right]^{2+}$ complexes and respective free ligands were also characterized by ${ }^{1} \mathrm{H}$ and ${ }^{13} \mathrm{C}$ NMR spectroscopy. In the ${ }^{1} \mathrm{H}$ NMR spectra of 1,10 -phenanthroline in DMSO- $d_{6}$ four types of aromatic protons appear in the range of 7.7-9.1 ppm. In its corresponding Zn-complex 6, these are shifted downfield, appearing between 8.1 and 9.0 ppm. 5-Amino-1,10-phenanthroline in $\mathrm{CD}_{3} \mathrm{OD}$ shows the presence of seven types of proton peaks (Fig. S1). However, in the spectra measured for 7 additional peaks are found, which cannot be assigned simply to the presence of free ligand. Thus, additional NMR studies were done $\left({ }^{13} \mathrm{C}, \mathrm{COSY}\right.$ and $\mathrm{HMBC}$ ) to assign the peaks and understand the solution behavior, which are described in the Supplemental Information. Overall, equilibrium takes place in the NMR time scale involving species with different ligand to metal ratios: 2:1 and 1:1, however, no free ligand was found upon dissolution of the complex, all species detected being $\mathrm{Zn}(\mathrm{II})$ complexes.

\subsection{Single crystal $X$-ray diffraction}

Slow evaporation of an ethanolic solution of $\mathbf{5}$ yielded single crystals suitable for single crystal X-Ray diffraction (XRD) studies, 
revealing a very interesting molecular structure, $\mathbf{5 a}$, shown in Fig. 2. Crystallographic details are summarized in Table S6 and selected interatomic distances and angles are presented in Table S7.

The molecular structure of $\mathbf{5 a}$ reveals a dinuclear complex with both $\mathrm{Zn}$ (II) centers presenting six-coordinated geometry. One zinc atom $(Z n 2)$ is bound to two Sal-Gly ligands while the other $(Z n 1)$ is bound to two phenanthroline ligands and to the two phenolate $\mathrm{O}$ atoms $\left(\mathrm{O}_{\text {phenolate }}\right)$ of the Sal-Gly ligands, which are shared between the $\mathrm{Zn}$-atoms. The dinuclear complex is formally neutral being composed by an anionic $\left[\mathrm{Zn}(\mathrm{Sal}-\mathrm{Gly})_{2}\right]^{2-}$ and a cationic $[\mathrm{Zn}$ $\left.(\text { Bphen })_{2}\right]^{2+}$ species that are bound through the $O_{\text {phenolate }}$ bridges. This type of arrangement of the phenanthroline ligands, giving rise to two metal centers with different coordination spheres, is not common and only one example of a similar Ni dinuclear compound was found in the literature [61]. The elemental composition of monomer 5 and dinuclear $5 \mathbf{a}$ are indistinguishable. However, we do not expect this type of dinuclear arrangement to correspond to the formulation of $\mathbf{1 - 5}$, as most structures found for ternary $\mathrm{Zn}(\mathrm{L})$ (phen) complexes are monomeric and $\mathbf{5 a}$ was obtained by slow evaporation of an ethanolic solution of complex $\mathbf{5}$, which took several weeks. Only a few crystals were obtained and thus, no other analytical analyses were made for $\mathbf{5 a}$, but a X-ray powder diffraction spectrum (XRPD) was simulated and compared with the one measured for complex 5, confirming that they correspond to different species (Fig. S4).

The $\mathrm{Zn}-\mathrm{N}_{\mathrm{Bphen}}$ bond lengths, ranging from 2.135(2) to 2.157(2) $\AA$, are in agreement with those found in the literature for this type of bonds [62-64]. A monomeric cationic $\mathrm{Zn}$ (II)-complex containing two phen molecules and a bidentate acetate showed similar $\mathrm{Zn}-\mathrm{N}$ bond lengths (2.133 to $2.140 \AA$ ) [65]. The $\mathrm{Zn}-\mathrm{O}_{\text {Phenolate }}$ and $\mathrm{Zn}$ $\mathrm{N}_{\text {imine }}$ bond distances [2.106(1) and 2.126(1); 2.076(2) and 2.090(2) $\AA$, respectively] are longer than those observed for Zn-Sal-Gly complexes, while the $\mathrm{Zn}-\mathrm{O}_{\text {carboxylate }}$ lengths [2.064(2) and $2.172(2) \AA]$ are within the values previously reported $[51,66]$.

\subsection{Stability in aqueous media}

All complexes are stable in DMSO, some up to $72 \mathrm{~h}$ (Fig. S5).
DMSO may replace the coordinated $\mathrm{H}_{2} \mathrm{O}$ molecule, but this substitution may be so fast that we cannot detect it by UV-Vis spectroscopy. Since one of the goals of the work is to evaluate the therapeutic potential of the $\mathrm{Zn}$-complexes as antitumor drugs, it is important to monitor their hydrolytic behavior in aqueous media in the $\mu \mathrm{M}$ range. Therefore, the complexes were dissolved in organic solvents, diluted in physiological $\mathrm{pH}$ buffer and their stability evaluated (Figs. S6-S10). The UV-visible absorption spectra measured in 5\% DMSO-PBS over time for $\mathbf{2}$ are shown in Fig. 3. Changes are seen within the first minutes, stabilizing after one hour. The band around $360-370 \mathrm{~nm}$, due to transitions in the imine bond, decreased with time, which is consistent with hydrolysis of this bond. This behavior, which is observed for all $\mathrm{Zn}$ (Sal-Gly)complexes, as well as the presence of isobestic points, corroborates the formation of new species. For $\mathbf{5}$ precipitation was also observed.

The UV-visible absorption spectra of complexes $\mathbf{6}$ and $\mathbf{7}$ depict almost no changes within $24 \mathrm{~h}$ in PBS buffered solutions (Fig. S12); probably changes do occur, but these happen immediately upon dissolution. In fact, the speciation diagrams calculated for the $\mathrm{Zn}$ phen system in the 1-100 $\mu \mathrm{M} Z \mathrm{Zn}$-concentration range (see Fig. $\mathrm{S} 26 \mathrm{~A})$ indicate that a mixture of $\mathrm{Zn}(\mathrm{II}),[\mathrm{Zn}(\text { phen })]^{2+},\left[\mathrm{Zn}(\text { phen })_{2}\right]^{2+}$ and $\left[\mathrm{Zn}(\text { phen })_{3}\right]^{2+}$ complexes exist, whose concentrations depend on the total amount of $\mathrm{Zn}(\mathrm{II})$ and $\mathrm{Zn}$ :phen molar ratio. The precursor $\left[\mathrm{Zn}(\mathrm{Sal}-\mathrm{Gly})\left(\mathrm{H}_{2} \mathrm{O}\right)_{2}\right]$ was also prepared and its stability evaluated, showing extensive hydrolysis occurring within one hour after dissolution in PBS buffer (Fig. S11).

The stability was also evaluated by measuring the fluorescence emission spectra of the complexes with time (Figs. S14-S16). Again, the Zn-Sal-Gly complexes are stable in DMSO but not in aqueous buffered solutions, while complexes 6 and $\mathbf{7}$ show only minor fluorescence intensity changes in both solvents. This was further corroborated for 1 and 6 by ${ }^{1} \mathrm{H}$ NMR spectroscopy. While 6 shows no changes in deuterated PBS buffer for $24 \mathrm{~h}$ (Fig. S18), complex 1, when dissolved in DMSO- $d_{6}$ and diluted with PBS (Fig. $\mathrm{S} 17)$, showed the appearance of a new peak at $10.15 \mathrm{ppm}$, which is assigned to an aldehyde $\mathrm{CHO}$ proton. Also, the peak assigned to the CHN imine proton (at $8.54 \mathrm{ppm}$ ) decreased its intensity and new peaks, probably corresponding to aromatic salicylaldehyde

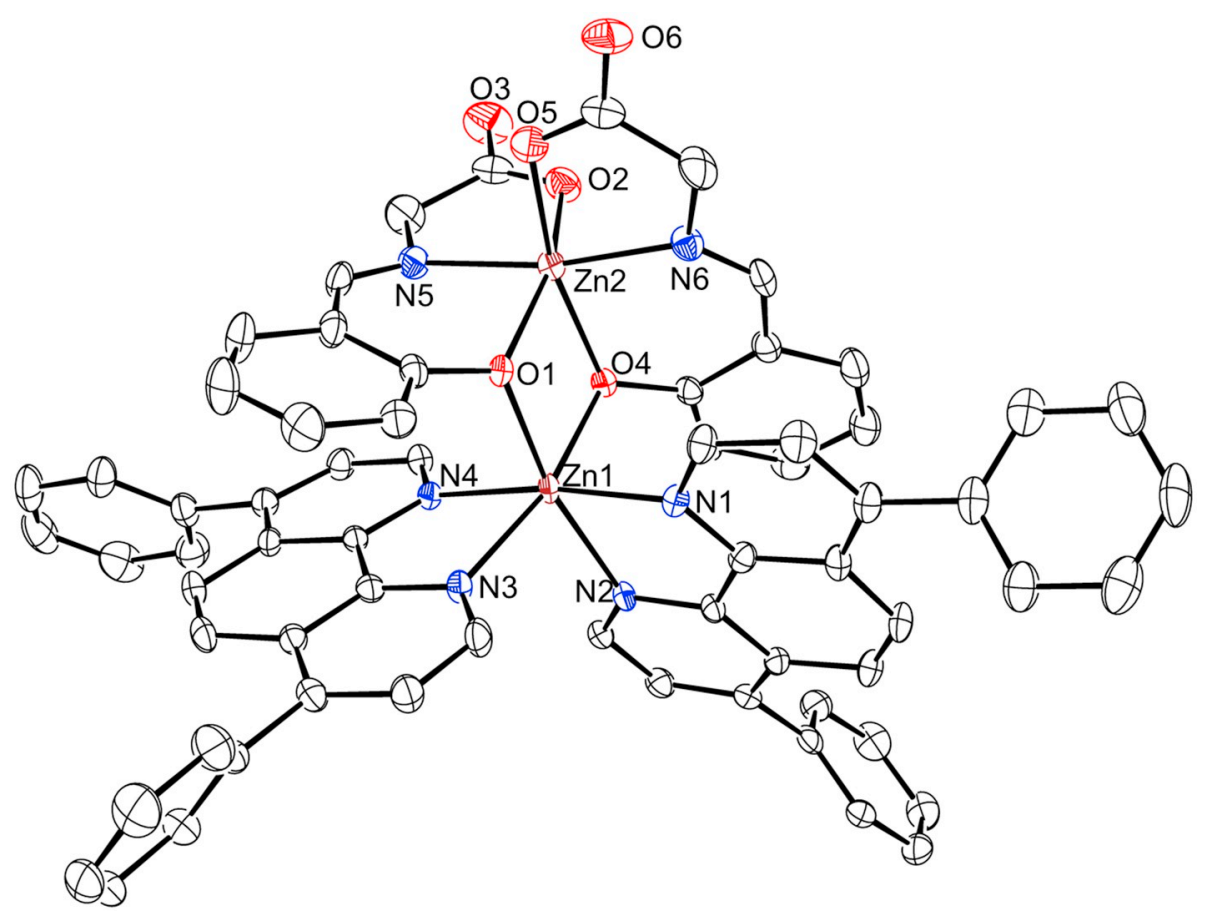

Fig. 2. ORTEP representation of the molecular structure of [Zn(Sal-Gly $\left.)_{2} Z n(B p h e n)_{2}\right](5 a)$, drawn with $50 \%$ thermal ellipsoids. Hydrogen atoms are omitted for clarity. Selected distances ( $\AA$ ): Zn1-N1 2.135(2), Zn-N2 2.157(2), Zn1-N3 2.145(2), Zn1N4 2.134(2), Zn1-01 2.111(2), Zn1-O4 2.106(1), $\mathrm{Zn2}-\mathrm{O} 1 \quad 2.126(1), \quad \mathrm{Zn} 2-\mathrm{O} 2 \quad 2.064(2), \quad \mathrm{Zn} 2-\mathrm{O} 4$ 2.101(2), Zn2-O5 2.172(2), Zn2-N5 2.090(2), Zn2N6 2.076(2). 

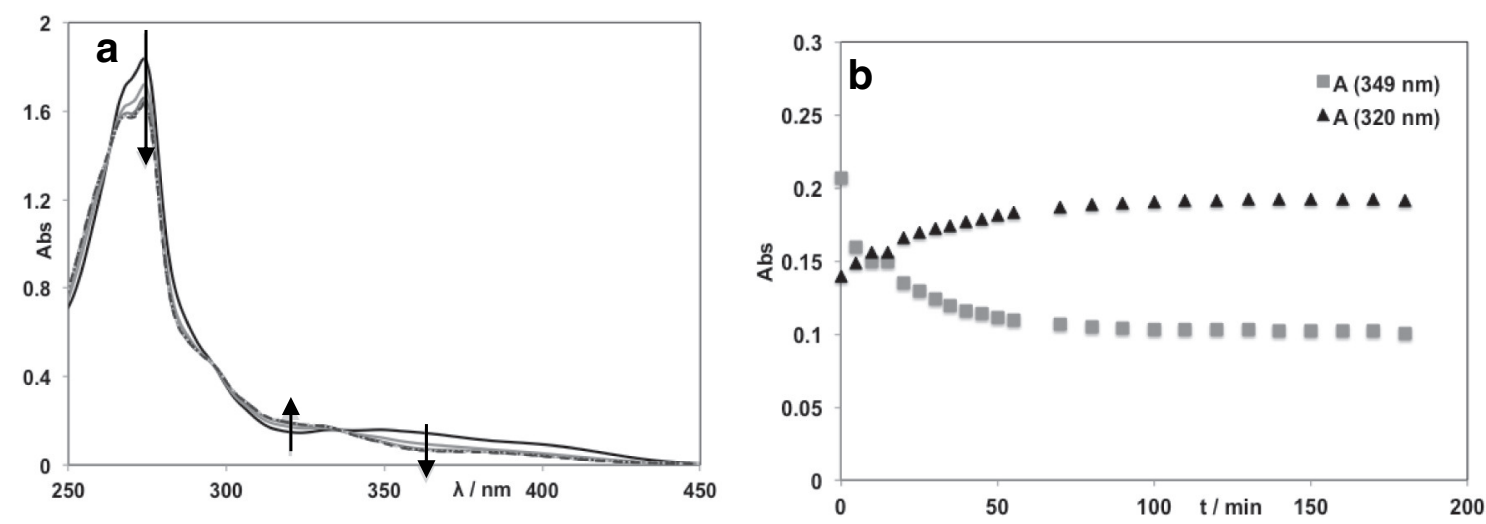

Fig. 3. a) Electronic absorption spectra recorded for 2 in PBS with $5 \%$ DMSO, measured over time; b) changes observed in the absorbance at 320 and $349 \mathrm{~nm}$ with time; [2] = $56 \mu \mathrm{M}$.

protons, appeared in the $6.5-8.0 \mathrm{ppm}$ region. Overall, this confirms that the Schiff bases hydrolyze in aqueous media. At lower concentrations this becomes even more critical, as evidenced by ESI$\mathrm{MS}$, in which solutions of $\mathbf{1}$ at $c a .10 \mu \mathrm{M}$ were evaluated with time, showing that no peaks assignable to $\left[\mathrm{Zn}(\mathrm{Sal}-\mathrm{Gly})(\right.$ phen $\left.)\left(\mathrm{H}_{2} \mathrm{O}\right)\right]$ species were present (data not shown). Speciation diagrams calculated for the systems Zn-Sal-Gly (taking stability constants from refs. $[67,68])$ and $\mathrm{Zn}$-Sal-Gly-phen in the $\mathrm{Zn}$-concentration range 1-1000 $\mu \mathrm{M}$ (section SI-7) corroborate the extensive hydrolysis.

These experiments demonstrate that at the concentrations relevant for the cytotoxicity studies, in the low $\mu \mathrm{M}$ range, the active species is no longer the originally $\left[\mathrm{Zn}(\mathrm{Sal}-\mathrm{Gly})(\mathrm{NN})\left(\mathrm{H}_{2} \mathrm{O}\right)\right]$ dissolved complex, but may be the bioactive free NN, the products of the hydrolyzed Sal-Gly Schiff base or the result of a combined effect of the ligands and Zn(II), or a new Zn(II) species formed with other bioligands present in the cell culture media. This was one of the motivations for the preparation and biological evaluation of the $\left[\mathrm{Zn}(\mathrm{NN})_{2}\right]^{2+}$ complexes.

\subsection{Cell studies}

\subsubsection{Cytotoxicity assays}

Despite the low hydrolytic stability of complexes 1-5, their cytotoxicity was evaluated in order to have data for comparison with the ligands and the $\left[\mathrm{Zn}(\mathrm{NN})_{2}\right]^{2+}$ complexes. Thus, the cytotoxic activity of the $\mathrm{Zn}$-compounds and respective ligands was evaluated against a panel of human cancer cells: ovarian (A2780), breast (MCF7) and cervical carcinoma (HeLa), as well as a non-tumoral cell line (V79 fibroblasts). The precursor [ $\left.\mathrm{Zn}(\mathrm{Sal}-\mathrm{Gly})\left(\mathrm{H}_{2} \mathrm{O}\right)_{2}\right]$ and cisplatin were also assessed for comparison (Table 1$)$.

In general, all compounds are more cytotoxic towards the A2780 cell line, showing the following cytotoxicity order: A2780 > MCF7 > HeLa. In the ovarian cells the IC $_{50}$ values upon $48 \mathrm{~h}$ incubation, ranging between 0.5 and $26 \mu \mathrm{M}$, are lower than or comparable to cisplatin $\left(\mathrm{IC}_{50}=22.5 \mu \mathrm{M}\right)$ under the same conditions. The $\left[\mathrm{Zn}(\mathrm{Sal}-\mathrm{Gly})\left(\mathrm{H}_{2} \mathrm{O}\right)_{2}\right]$ precursor shows no cytotoxicity, emphasizing the active contribution of the polypyridyls to the biological activity of the complexes. However, the polypyridyl ligands per se displayed considerable activity, the $\mathrm{IC}_{50}$ values being in general of the same order of magnitude or even lower than the corresponding complexes.

When comparing the $\mathrm{IC}_{50}$ values obtained in the ovarian $\mathrm{A} 2780$ cell lines for the pairs $\left[\mathrm{Zn}(\mathrm{Sal}-\mathrm{Gly})(\right.$ phen $\left.)\left(\mathrm{H}_{2} \mathrm{O}\right)\right]$ (1) and $[\mathrm{Zn}$ (phen) $\left.)_{2}\left(\mathrm{H}_{2} \mathrm{O}\right)_{2}\right]^{2+}(6)$ and/or [ $\mathrm{Zn}(\mathrm{Sal}-\mathrm{Gly})\left(\right.$ amphen) $\left.\left(\mathrm{H}_{2} \mathrm{O}\right)\right](3)$ and $\left[\mathrm{Zn}(\text { amphen })_{2}\left(\mathrm{H}_{2} \mathrm{O}\right)_{2}\right]^{2+}(7)$ it appears that the values obtained for the $\left[\mathrm{Zn}(\mathrm{NN})_{2}\left(\mathrm{H}_{2} \mathrm{O}\right)_{2}\right]^{2+}$ in all cancer cells are roughly half the values measured for $\left[\mathrm{Zn}(\mathrm{Sal}-\mathrm{Gly})(\mathrm{NN})\left(\mathrm{H}_{2} \mathrm{O}\right)\right]$. Considering that each $\left[\mathrm{Zn}(\mathrm{NN})_{2}\left(\mathrm{H}_{2} \mathrm{O}\right)_{2}\right]^{2+}$ contains two moles of the NN derivative, this suggests that the active species is the NN ligand. This is further substantiated by the results obtained with phen and 6 i.e., in A2780 cell line the $\mathrm{IC}_{50}$ value obtained for the phen ligand $(5.84 \pm 2.3 \mu \mathrm{M})$ is roughly twice the one obtained for 6 $(2.4 \pm 1.3 \mu \mathrm{M})$. The same is observed for amphen and 7. The low hydrolytic stability observed for the $\mathrm{Zn}$ (Sal-Gly)-complexes gives further support to these considerations. Higher activity of the amphen when compared with its $\mathrm{Ru}(\mathrm{II})$-complex $\left[\left(\eta^{6}-p\right.\right.$-cymene $) \mathrm{RuCl}$ $\left(\kappa^{2}\right.$-amphen)]Cl [69] upon $96 \mathrm{~h}$ incubation were also reported in experiments with $\mathrm{A} 2780$ and MCF7 cells.

Regarding free $\mathrm{Zn}^{2+}$ ions $\left(\mathrm{ZnCl}_{2}\right)$, no cytotoxic activity was observed $\left(\mathrm{IC}_{50}>100 \mu \mathrm{M}\right)$ in the ovarian cells during $48 \mathrm{~h}$ incubation in the same concentration range of the complexes $(0.01 \mu \mathrm{M}-100 \mu \mathrm{M})$. This is compatible with the reported statement that $\mathrm{Zn}^{2+}$ is hydrophilic and hence cannot cross the plasma membrane or the other membranes of intracellular components to induce an effect [70].

The selectivity of the complexes towards cancer cells was evaluated by testing the complexes against the non-tumoral V79 hamster fibroblasts. Despite the non-malignant cell line being of a different species and tissue it can give an overall idea of the compounds' selectivity. As shown in Table 1, for most Zn-complexes the selectivity index (A2780 vs. V79 cells) is higher $(\mathrm{SI}>2$ ) than for the control drug cisplatin $(S I=1)$ and in the case of complexes 6 and 7, much higher than their respective ligands. The most selective $(\mathrm{SI}>4)$ are compounds $1,4,6$ and 7 . One of the most active complexes, $\mathbf{5}$, which shows $\mathrm{IC}_{50}$ values in the low $\mu \mathrm{M}$ range in all cancer cell lines, is also highly toxic towards the fibroblasts, showing low selectivity.

Since the activity at $48 \mathrm{~h}$ appears to arise from the NN aromatic heterocycle, additional studies were made with complexes $\mathbf{6}$ and $\mathbf{7}$, as well as their corresponding NN ligands, incubating A2780 and MCF7 cells with the compounds for shorter time periods. Although in some cases the SD values are relatively high the results depicted in Fig. S19 globally show that: (i) the cytotoxicity is time dependent, as expected, with the same trend for both cells; additionally, (ii) at $3 \mathrm{~h}$, all compounds display similar cytotoxicity in both cell lines, with 7 being more active in the ovarian than the breast cells; (iii) at $24 \mathrm{~h}$ the amphen is equally active in both cells but its corresponding complex $\mathbf{7}$ is more cytotoxic in the breast than the ovarian cells; (iv) for the MCF7 cells at $24 \mathrm{~h}$ the complexes are much more cytotoxic than the NN ligands.

This additional study at different incubation times shows that some of the conclusions based on the results obtained at $48 \mathrm{~h}$ of incubation were misrepresentative of the activity of the complexes compared with their corresponding NN ligands. Considering shorter incubation periods, in the ovarian cancer cells the ligands and respective complexes perform similarly, however in the breast 
Table 1

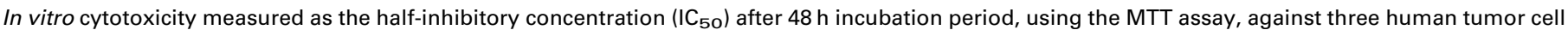

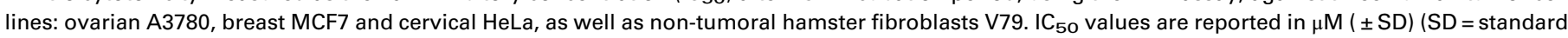
deviation).

\begin{tabular}{|c|c|c|c|c|c|}
\hline Compounds & A2780 & MCF7 & $\mathrm{HeLa}$ & V79 & $\mathrm{SI}^{\mathrm{a}}$ \\
\hline$\left[\mathrm{Zn}(\mathrm{Sal}-\mathrm{Gly})\left(\mathrm{H}_{2} \mathrm{O}\right)_{2}\right]$ & $>100$ & $>100$ & $>100$ & $>100$ & - \\
\hline$\left[\mathrm{Zn}(\mathrm{Sal}-\mathrm{Gly})(\right.$ phen $\left.)\left(\mathrm{H}_{2} \mathrm{O}\right)\right] \mathbf{1}$ & $5.8 \pm 3.0$ & $17.6 \pm 10.0$ & $26.9 \pm 9.5$ & $23.9 \pm 6.5$ & 4.1 \\
\hline$\left[\mathrm{Zn}(\mathrm{Sal}-\mathrm{Gly})(\mathrm{Clphen})\left(\mathrm{H}_{2} \mathrm{O}\right)\right] 2$ & $25.9 \pm 5.3$ & $21.8 \pm 12.6$ & $37.7 \pm 15.5$ & $28.1 \pm 5.9$ & 1.1 \\
\hline$\left[\mathrm{Zn}(\mathrm{Sal}-\mathrm{Gly})(\right.$ amphen $\left.)\left(\mathrm{H}_{2} \mathrm{O}\right)\right] \mathbf{3}$ & $3.40 \pm 2.8$ & $12.3 \pm 6.11$ & $15.9 \pm 8.6$ & $10.8 \pm 6.5$ & 3.2 \\
\hline$\left[\mathrm{Zn}(\mathrm{Sal}-\mathrm{Gly})\left(\right.\right.$ epoxyphen) $\left.\left(\mathrm{H}_{2} \mathrm{O}\right)\right] 4$ & $5.6 \pm 0.9$ & $18.2 \pm 4.5$ & $23.7 \pm 6.5$ & $33.6 \pm 11$ & 6.0 \\
\hline$\left[\mathrm{Zn}(\mathrm{Sal}-\mathrm{Gly})(\right.$ Bphen $\left.)\left(\mathrm{H}_{2} \mathrm{O}\right)\right] \mathbf{5}$ & $1.73 \pm 0.4$ & $3.04 \pm 1.2$ & $4.58 \pm 1.0$ & $4.06 \pm 0.55$ & 2.3 \\
\hline$\left.\left[\mathrm{Zn}(\text { phen })_{2}\right)\left(\mathrm{H}_{2} \mathrm{O}\right)_{2}\right]^{2+} 6$ & $2.4 \pm 1.3$ & $9.10 \pm 3.7$ & $16.6 \pm 7.0$ & $14.2 \pm 7.8$ & 5.9 \\
\hline$\left.\left[\mathrm{Zn}(\text { amphen })_{2}\right)\left(\mathrm{H}_{2} \mathrm{O}\right)_{2}\right]^{2+} 7$ & $0.75 \pm 0.13$ & $5.42 \pm 2.1$ & $8.16 \pm 4.3$ & $6.78 \pm 3.9$ & 9.0 \\
\hline phen & $5.84 \pm 2.3$ & $6.21 \pm 2.2$ & $11.8 \pm 3.6$ & $7.10 \pm 3.0$ & 1.2 \\
\hline Clphen & $5.70 \pm 3.0$ & $10.0 \pm 2.8$ & $12.0 \pm 2.2$ & $9.50 \pm 2.3$ & 1.7 \\
\hline amphen & $1.84 \pm 0.56$ & $4.41 \pm 2.8$ & $7.20 \pm 1.3$ & $3.90 \pm 1.8$ & 2.1 \\
\hline epoxyphen & $14.4 \pm 3.5$ & $10.0 \pm 4.2$ & $18.4 \pm 4.2$ & $18.7 \pm 5.0$ & 1.3 \\
\hline Bphen & $0.50 \pm 0.5$ & $3.20 \pm 0.9$ & $2.00 \pm 0.5$ & $1.20 \pm 0.7$ & 2.4 \\
\hline Cisplatin & $22.5 \pm 5.0$ & $20.7 \pm 6.4$ & $3.59 \pm 2.2$ & $23.5 \pm 5.0$ & 1.0 \\
\hline
\end{tabular}

a The selectivity index (SI) was calculated for the $A 2780$ cells: $I C_{50}(V 79) / I C_{50}(A 2780)$.

cancer cells, the complexes are more active than the ligands, thus not only the metal plays a relevant role but the type of cell line also. Therefore, to directly conclude that the active species is the NN ligand is putting the observations in too simplistic terms.

\subsubsection{ROS production}

Most of the anticancer agents (e.g., cisplatin) induce the formation of highly reactive oxygen species (ROS) revealed by the elevation of lipid peroxidation products and reduction of the antioxidant status. ROS at high levels can activate cell death mechanisms and induce apoptosis [71,72]. Generally $\mathrm{Zn}(\mathrm{II})$ has a protective role against oxidative stress [73]. However, it has been shown that increased levels of intracellular zinc may impair antioxidant mechanisms such as the glutathione system [74], or mitochondrial functions [70], which may result in increased production of ROS [75]. ROS such as superoxide can be detected with NBT, a cell permeant dye that can cross the cell membrane and be reduced by intracellular free radicals (superoxide anions) to form formazan compounds, detected as blue precipitates in lysed cells. As shown in Fig. 4A, complexes 2-5 (not clear for $\mathbf{1}$ ) increased the ROS levels in a dose-dependent manner with ROS production being considerably higher when compared with controls (untreated cells) and with the precursor. Complexes 2 and 3 at $10 \mu \mathrm{M}$ showed greater effect on the ROS levels than $\mathbf{5}$ under the same conditions, suggesting that ROS production is not completely correlated with the cytotoxic activities displayed by these complexes. The free NN ligands also increased the ROS levels but not in a dose-dependent manner and to a lesser extent than the complexes. The free $\mathrm{Zn}$ (II) ions in the form of $\mathrm{ZnCl}_{2}$ did not induce $\mathrm{ROS}$ production in the ovarian cells in a wide concentration range $\left(10^{-7}-10^{-3} \mathrm{M}\right)$ (Fig. S20). This result correlates with the statement that $\mathrm{Zn}^{2+}$ is not expected to enter inside the cells [81]. Tetrazolium salts like MTT and NBT are converted to colored formazan crystals and this reduction occurs inside metabolically active cells. The $\mathrm{Zn}$ complexes entered the cells and therefore a reduction effect of NBT occurred.

\subsubsection{Caspase assays}

Caspases, a family of cysteine proteases, regulate ordered processes such as apoptotic signaling pathways. Among them, caspase- 3 and caspase- 7 are considered executioners of the apoptosis pathways. Activation of the caspase-3/7 pathway can be used in cellular assays to quantify activators and inhibitors of the cell death cascade [76-78]. We explored the use of the active form of caspase- 3 and 7 for the detection of apoptotic events induced by the $\mathrm{Zn}(\mathrm{Sal}-\mathrm{Gly})(\mathrm{NN})$-complexes, since there have been reports that cells undergo apoptosis when exposed to metal polypyridyl complexes [79]. As depicted in Fig. 5 the ability of the compounds to activate caspase-3/7 in vitro is not directly correlated with their ability to induce cell death. Complex 2, which exhibited moderate cytotoxicity and is the less active compound in the series, showed the highest caspase activation in contrast to $\mathbf{5}$, that showed no sign of apoptosis in relation to controls or even inhibited apoptosis. While 1-4 induce cell death by apoptosis, results suggest that complex $\mathbf{5}$ may induce cell death by other mechanisms. The free ligands followed, in general, the same trend i.e., their ability to activate caspase-3/7 did not correlate with their cytotoxic activity.

\subsubsection{Cellular uptake and distribution}

Cellular uptake studies were carried out to evaluate the distribution and localization of $\mathrm{Zn}$ inside the A2780 cells upon incubation with three complexes (1, $\mathbf{3}$ and $\mathbf{6})$, and also to assess their potential cellular targets. These complexes present high cytotoxicity (at $48 \mathrm{~h}$ incubation) and induce apoptosis (6 was not evaluated). For this study $A 2780$ cells were incubated for $24 \mathrm{~h}$ at $37^{\circ} \mathrm{C}$ with the complexes at concentrations equivalent to their $\mathrm{IC}_{50}$ values (at $24 \mathrm{~h}$ ), respectively 100, 30 and $100 \mu \mathrm{M}$. The $\mathrm{Zn}$ content was determined in cytoplasm, membranes, nucleus and cytoskeleton using ICP-MS. As depicted in Fig. 6, all complexes (or Zn-containing species derived from them) enter the cells but present quite different distribution profiles; for $\mathbf{3}$ the $\mathrm{Zn}$ is found in roughly the same amount ( $25 \%$ of total uptake) in all the cellular fractions, while for complex $\mathbf{1}$ the metal ion is mainly retained in the cytosol fraction (60\% total uptake) and for 6 mainly in the membranes fraction (56\% total uptake) (Fig. 6B). Importantly, $\mathrm{Zn}$ was also found in the nucleus, at a higher percentage (and absolute amount) for complex 3 (the most cytotoxic at $24 \mathrm{~h}$ of the three compounds), when compared to 1 ( 26 vs. $9 \%$ ) or 6 ( 26 vs. $14 \%$ ). Noteworthy, the absolute amount of $\mathrm{Zn}$ entering the cells is globally higher in the case of incubation with $30 \mu \mathrm{M}$ of complex 3 than upon incubation with $100 \mu \mathrm{M}$ of complex 6 .

Overall, these results also support the idea that the cytotoxicity might not be solely/simply due to the polypyridyl ligand, as complexes 1 and $\mathbf{6}$, both containing the phen molecule, accumulate preferentially in different compartments. In fact, the distinct nature of the NN ligand is also causing distinct distribution of $\mathrm{Zn}$ in the cellular compartments. 

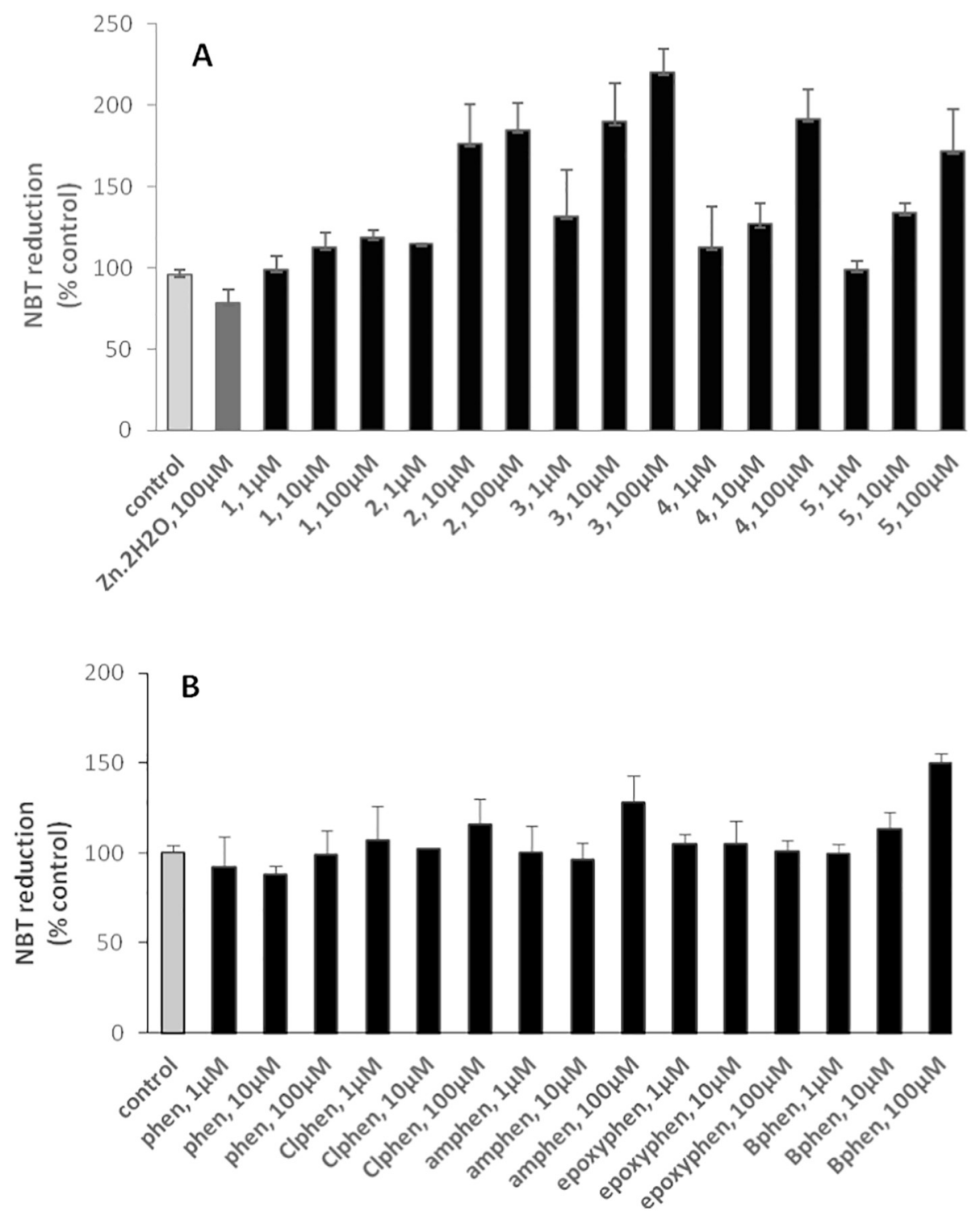

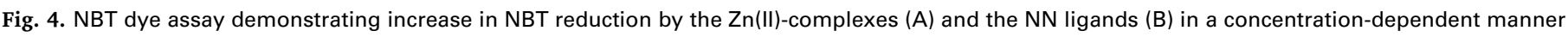
after treatment of $\mathrm{A} 2780$ cells with the compounds. $\mathrm{Zn} .2 \mathrm{H}_{2} \mathrm{O}$ corresponds to $\left[\mathrm{Zn}(\mathrm{SalGly})\left(\mathrm{H}_{2} \mathrm{O}\right)_{2}\right.$ ].

\subsubsection{Morphological \\ analysis \\ by \\ transmission \\ electron} microscopy (TEM)

The ultrastructural alterations at cellular organelle level were also evaluated for complexes 1 and 3 by TEM studies, in the conditions described in Fig. 7. Results showed that, upon treatment with 1 (Fig. 7 c, d and S21B), A2780 cells suffered marked mitochondrial changes and morphological alterations typical of cell death, including the presence of electron-dense floccular material in the matrix, in contrast with the cell morphology depicted in Fig. 7 $a, b$ (control cells, see also Fig. S21A) where a normal variation of the mitochondria and nucleus structures were observed.

Treatment with 3 induced milder mitochondrial changes, but the nuclear membrane showed marked indentations and larger nucleoli (Fig. 7 e, f and Fig. 21C). Apoptotic features were present in both treatments, but in a more advanced stage for $\mathbf{1}$. These effects are consistent with caspase activation detected for both complexes, in particular complex 1, and perhaps in agreement with the higher increased cytosol association of $\mathbf{1}$ and significantly higher nuclear association of $\mathbf{3}$.

\subsubsection{Membrane lipid peroxidation}

Quantification of lipid peroxidation is very important to assess oxidative stress in several processes. Lipid peroxides are one of the most widely used indicators of free radical formation, a key biomarker of oxidative stress. These products are unstable and decompose to form a complex series of compounds, which include reactive carbonyl compounds, such as MDA and lipid alkenals such as 4-HNE [80]. Measurement of lipid peroxidation has relied on the detection of thiobarbituric acid (TBA) reactive compounds generated from the decomposition of lipid peroxidation products. This reaction, which takes place under acidic conditions at $95-100^{\circ} \mathrm{C}$, results in the formation of a MDA-TBA adduct that can be quantified by its absorbance at $532 \mathrm{~nm}$.

The basal level of lipid peroxides in the A2780 cells was $0.5 \mathrm{nmol} / 10^{6}$ cells (Table 2). Complexes increased lipid peroxide level in the ovarian cells by more than three times for 1 and 2 and $>10$ times for $\mathbf{3}, \mathbf{4}$ and $\mathbf{5}$.

\subsection{DNA binding studies}

Although we tried to evaluate the ternary $[\mathrm{Zn}(\mathrm{Sal}-\mathrm{Gly})(\mathrm{NN})$ 

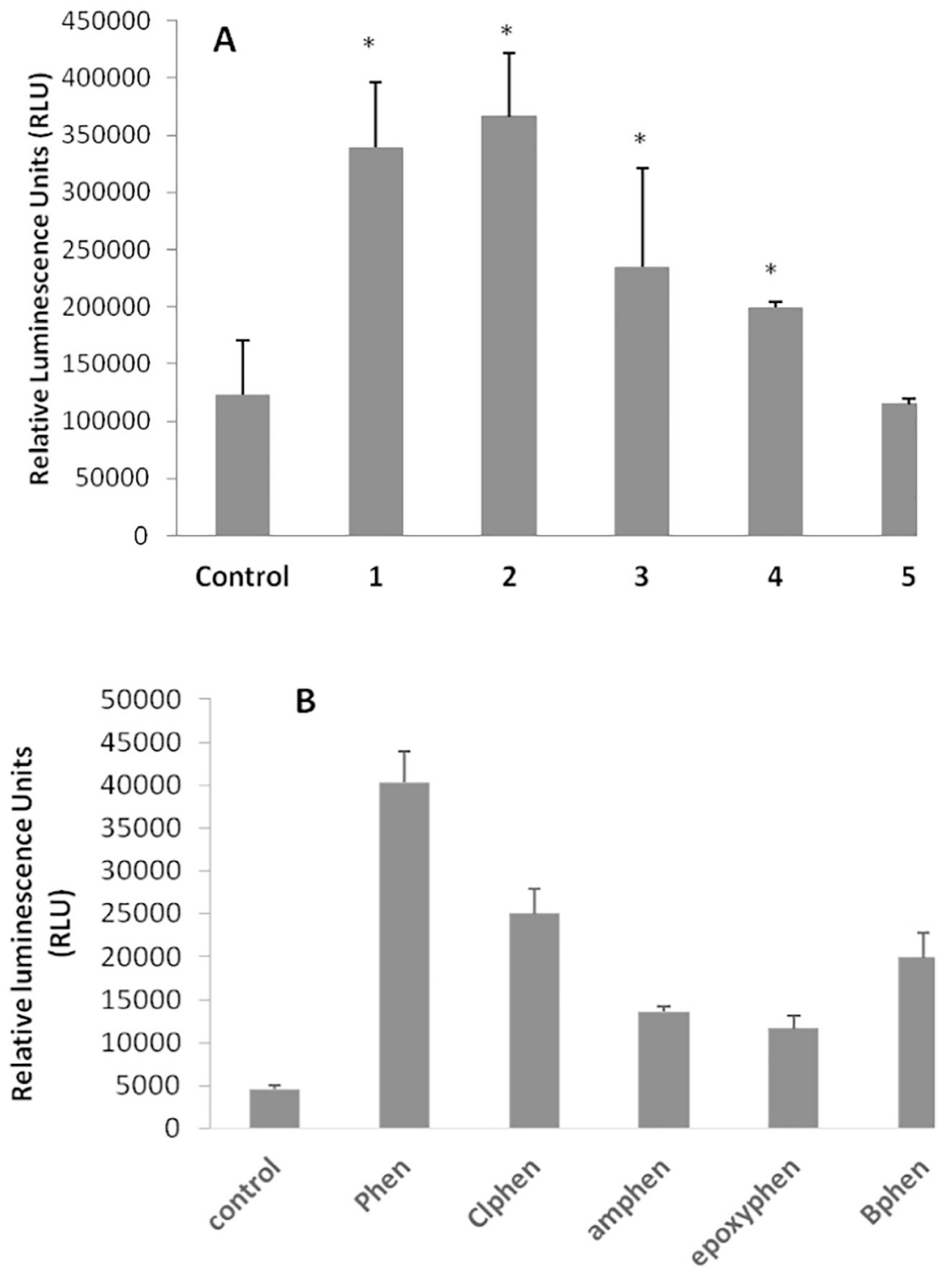

Fig. 5. Caspase Assays. A) Complexes 1-4, but not 5 induce apoptosis in A2780 cells. B) All the free ligands induced apoptosis in particular phen and Clphen to a higher extent. The apoptotic effect was evaluated by CaspaseGlo assay after cell treatment for $48 \mathrm{~h}$, using for each compound the concentration corresponding to its $I_{50}$ value. Data was obtained from three replicates per assay and was expressed as the mean $\pm S D$, in relative luminescent units. ${ }^{*} p<0.05$ (graph A). Results are representative of two independent experiments. Although in Fig. 5A some of the values are not significantly different, some global trends may be concluded.
$\left(\mathrm{H}_{2} \mathrm{O}\right)$ ] complexes, their low stability in aqueous media precluded making a reliable study. In section $\mathrm{SI}-10$ we present a few speciation diagrams that help demonstrate the very extensive hydrolysis expected for the $\left[\mathrm{Zn}(\mathrm{Sal}-\mathrm{Gly})(\mathrm{phen})\left(\mathrm{H}_{2} \mathrm{O}\right)\right]$ complex in the typical low concentration conditions used in studies of binding of metal complexes to $c t \mathrm{DNA}$. The homoleptic $\mathrm{Zn}$-polypyridyl complexes, 6 and 7, were evaluated towards their ability to bind DNA. It has been reported that metal complexes containing planar aromatic a

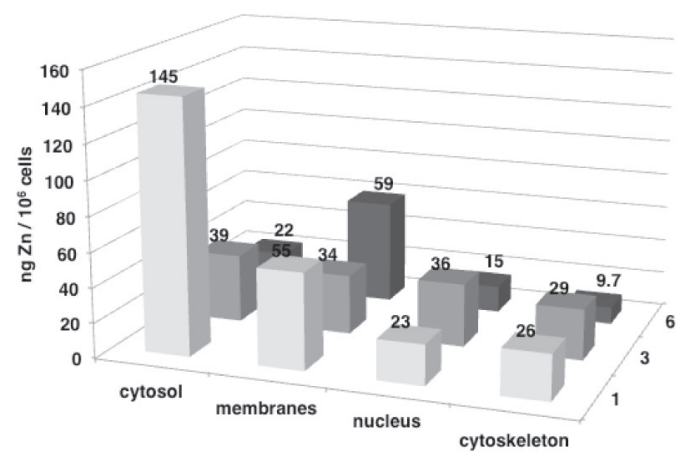

b

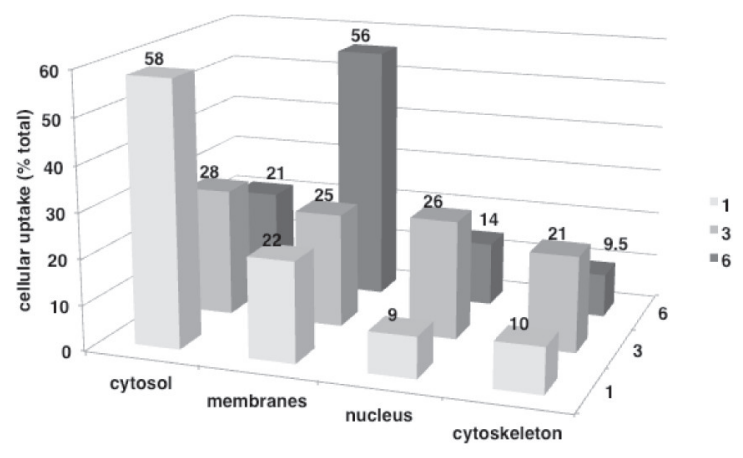

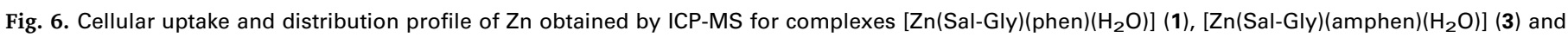

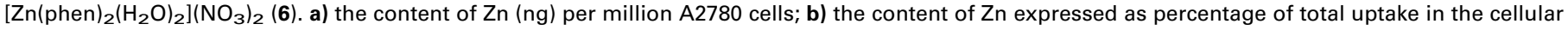
fractions. 


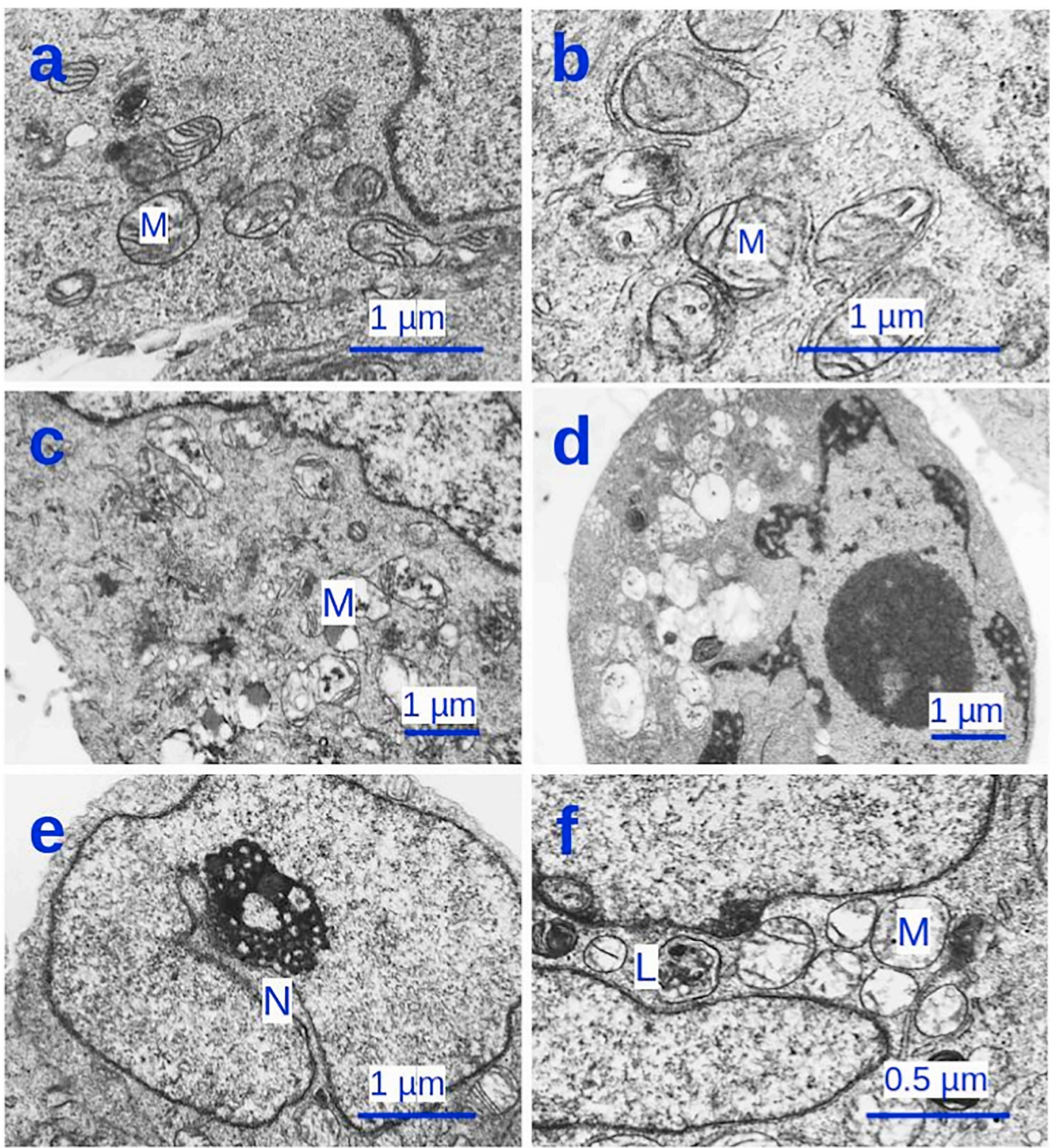

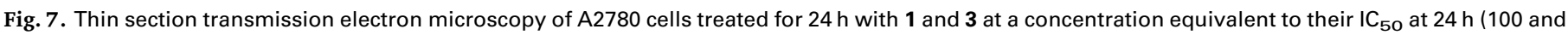

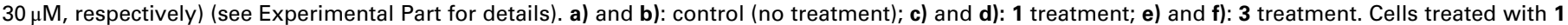

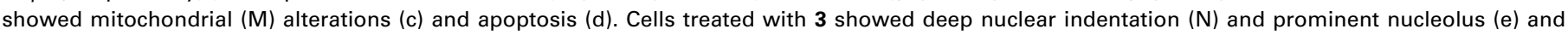
swollen mitochondria (M) and lysosomes (L) with variable contents (f).

heterobases, such as the present NN derivatives, are able to bind DNA by intercalative and non-intercalative modes [21-23,81]. Spectroscopic techniques, namely UV-Vis absorption and fluorescence quenching measurements have been usually applied to determine the binding mode and estimate binding constants. We should emphasize that, as demonstrated in Fig. S29A, if Zn-phen complexes are dissolved in aqueous solution, they undergo speciation and several $\mathrm{Zn}$-phen complexes will co-exist $[\mathrm{Zn}(\mathrm{phen})]^{2+}$, $\left[\mathrm{Zn}(\text { phen })_{2}\right]^{2+}$ and $\left[\mathrm{Zn}(\text { phen })_{3}\right]^{2+}$, and in theory all may bind to DNA.

\subsubsection{UV-Vis absorption spectroscopy}

The conditional binding constants for the free phen and amphen, as well as overall constants for complexes $\mathbf{6}$ and $\mathbf{7}$ were determined by monitoring changes in the UV-vis absorption spectra of solutions containing the compounds that were titrated with increasing amounts of ctDNA (see Fig. S22). The spectra measured for $\mathbf{7}$ are shown in Fig. 8, as well as changes observed at maximum wavelengths. Isobestic points are clearly detected at 300,315 and $355 \mathrm{~nm}$, indicating equilibrium between two spectroscopic forms of the complex, free and associated with DNA. The variation of molar absorptivity is plotted in the inset at two selected wavelengths. The spectroscopic results were used to determine binding constants for the association of phen, amphen, 6 and 7 with DNA assuming the formation of a 1:1 complex (see details in SI-4). The values of the determined conditional binding constants are compiled in Table S8. Similar binding affinities with $K_{\mathrm{a}}$ values between $10^{3}$ and $10^{4} \mathrm{M}^{-1}$ were obtained for both ligands and 7, while 6 showed a much lower value of $K_{a}$.

\subsubsection{Circular dichroism spectroscopy}

DNA shows circular dichroism spectra in the UV arising from the coupling of the stacked planar bases, which adopt a chiral helical arrangement. Calf Thymus DNA circular dichroism (CD) spectrum displays a positive band centered at ca. $275 \mathrm{~nm}$ (due to base stacking), and a negative band centered at ca. $245 \mathrm{~nm}$ 
Table 2

Lipid peroxide (MDA) content in the A2780 cells. Cells were treated with complexes $\mathbf{1}-\mathbf{5}$ for $24 \mathrm{~h}$ at a concentration equivalent to $2 \times$ their $\mathrm{IC}_{50}$. Results are expressed as mean $\pm \mathrm{SD}$ from two separate experiments in which triplicate measurements were made.

\begin{tabular}{ll}
\hline Culture conditions & MDA (nmol/10 ${ }^{6}$ cells) \\
\hline Cells only (no treatment) & $0.47 \pm 0.06$ \\
$\mathbf{1}(10 \mu \mathrm{M})$ & $1.81 \pm 0.32$ \\
$\mathbf{2}(50 \mu \mathrm{M})$ & $1.91 \pm 0.20$ \\
$\mathbf{3}(10 \mu \mathrm{M})$ & $6.90 \pm 0.91$ \\
$\mathbf{4}(10 \mu \mathrm{M})$ & $6.21 \pm 0.54$ \\
$\mathbf{5}(10 \mu \mathrm{M})$ & $8.42 \pm 0.66$ \\
\hline
\end{tabular}

(associated with right handed helicity), typical of $c t$ DNA in the right handed B-form [82]. Spectral changes in this region upon addition of compounds to solutions of DNA can be due to electrostatic interactions, major or minor grove binding or intercalation of the added compounds. Non-chiral molecules, such as the free ligands in this study, or racemic mixtures such as the presently studied Zncomplexes, have no intrinsic CD signal. However, if they bind to a chiral macromolecule such as DNA, an induced CD signal (ICD) may arise in the range where they absorb [83]. Typically, the ICD signals of intercalators are of low intensity $\left(\Delta \varepsilon<10 \mathrm{M}^{-1} \mathrm{~cm}^{-1}\right)$ and those of groove-binders are stronger [84]. If one of the enantiomers of the racemic mixture of a $\mathrm{Zn}$-complex binds preferentially to ctDNA, additional CD bands may develop.

Fig. 9 shows the circular dichroism spectra measured in systems containing ctDNA and increasing amounts of complexes 6 and 7, for the [Zn-complex]/[DNA] molar ratios indicated; Fig. S23 displays $C D$ spectra measured upon adding the free ligands phen and amphen to ctDNA solutions. It is clear from Fig. 9 that in both systems strong and distinct changes are observed, even for low molar ratios of added $\mathrm{Zn}$-complexes. For 6 the CD bands, particularly in the range $270-310 \mathrm{~nm}$, increase with additions of the complex (Fig. 9a), at least up to a molar ratio of ca. 1.0. This increase is much steeper than when only the free phen ligand is added to ctDNA (Fig. S23a); in this latter system there is an initial increase in the $\Delta \varepsilon$ values up to a molar ratio of 0.4 , and almost no further changes take place upon further additions. This is in agreement with intercalation of the phen molecules in between DNA base pairs since both the 275 and the $245 \mathrm{~nm}$ bands increase its intensity indicating lengthening of the DNA helix. It also corroborates that when complex 6 is added to ctDNA, it is a $\mathrm{Zn}$-containing species that binds to the macromolecule. The ICD bands are superimposed on the ctDNA spectrum, since this is the spectral region in which both DNA and the complex absorb (between 250 and $300 \mathrm{~nm}$ ). It presents positive bands with maxima at $277 \mathrm{~nm}$ and a shoulder at $296 \mathrm{~nm}$ and negative bands at ca. $257 \mathrm{~nm}$. The bands are quite strong, particularly the one at $277 \mathrm{~nm}$. Fig. S24 shows the circular dichroism spectra upon additions of an aqueous solution containing 1:1 molar concentrations of $\mathrm{Zn}\left(\mathrm{NO}_{3}\right)_{2}$ and phen, this simulating the addition of a $[\mathrm{Zn}(\text { phen })]^{2+}$ complex. The CD spectra are very similar to the ones obtained with 6, but those of Fig. S24 are less intense; these changes are also intermediate between the effects observed for complex 6 and those imposed by the phen ligand alone. Overall our data, namely the absence of clear isodichroic points, support the assumption that several phen-containing species exist in solution interacting with DNA. Moreover, the $\mathrm{Zn}$-phen species undergo speciation when added to the solution containing ctDNA (as indicated in Fig. S29A) and suggests that probably the main species that is binding to ctDNA is the [ $\mathrm{Zn}$ (phen)] ${ }^{2+}$ complex. For the very low 6:ctDNA molar ratios it is probably mostly phen that binds to ctDNA.

Upon addition of $\mathbf{7}$ to $c t D N A$, the changes in the $C D$ spectra are more drastic than for the $\mathrm{Zn}$-phen complexes in similar conditions (Fig. 9b): up to a molar ratio 7:ctDNA of ca. 0.4 positive bands at $\sim 303$ and $279 \mathrm{~nm}$ develop, and the negative band at $245 \mathrm{~nm}$ disappears, and upon further additions of 7 a negative strong band at $\sim 286 \mathrm{~nm}$ appears and the $303 \mathrm{~nm}$ band disappears. For the free amphen ligand up to a molar ratio of amphen:ctDNA of $c a$. 1.0, the $\mathrm{CD}$ spectra measured resemble those reported by Valladolid et al. [69] for the amphen:ctDNA system up to a molar ratio of 3 . In this latter work the $c t D N A$ used was sonicated to obtain DNA fragments with 1000 base-pairs, this probably explaining why we obtain distinct $C D$ spectra for the higher molar ratios of amphen:ctDNA. Overall, checking changes upon subtraction of the ctDNA spectrum, for ratios $<1$ the measured spectra show weak ICD bands at ca. $302 \mathrm{~nm} \mathrm{(+)} \mathrm{and} 280 \mathrm{~nm}(-)$. For ratios amphen:ctDNA $>1$ the $302 \mathrm{~nm}$ band disappears and negative bands at ca. 267 and $290 \mathrm{~nm}$ develop.

When a solution containing $\mathrm{Zn}\left(\mathrm{NO}_{3}\right)_{2}$ and amphen in 1:1 molar ratio is added to $c t D N A$, the global evolution of the $C D$ spectra is

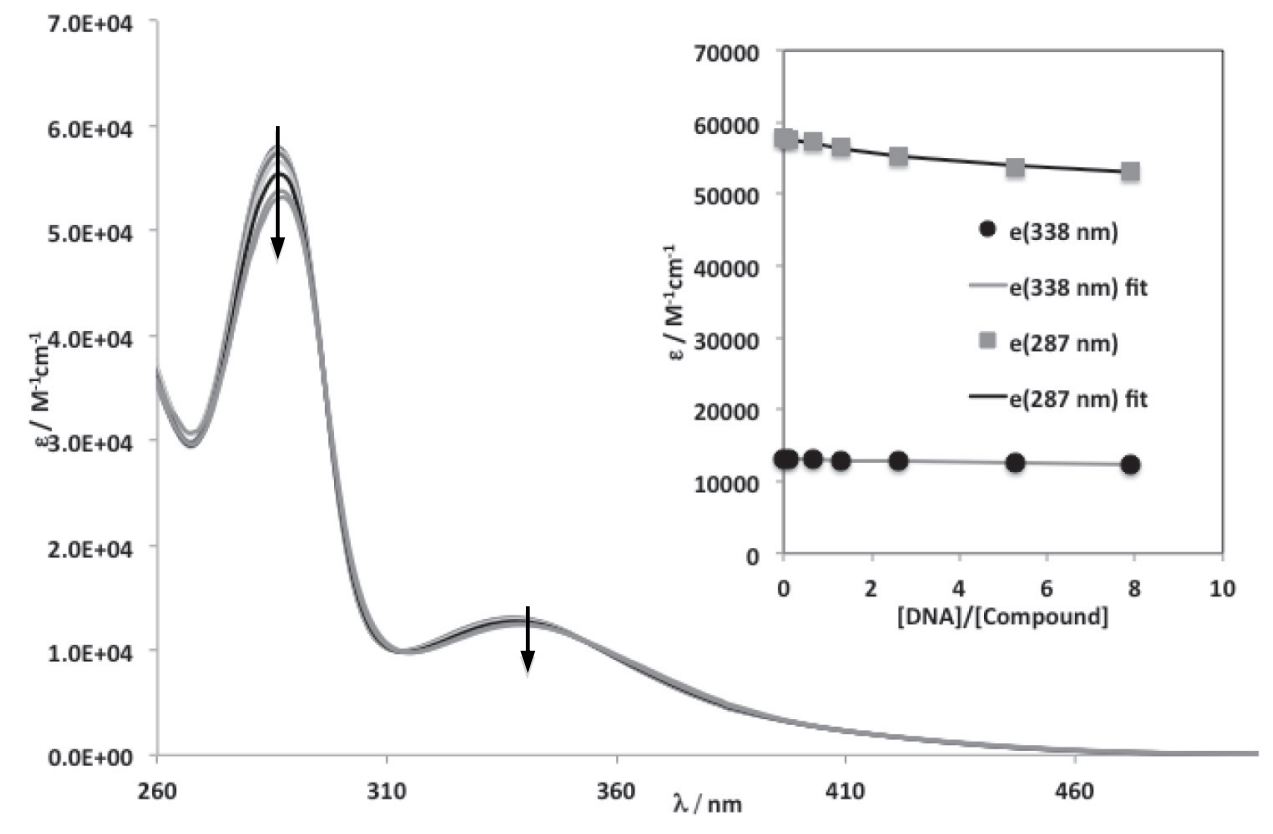

Fig. 8. UV-vis absorption spectra measured for the titration of a solution of $7\left(1.7 \times 10^{-5}\right.$ M) with increasing amounts of ctDNA (arrows indicate changes with DNA addition), after dilution correction. The same amount of DNA was added in the reference cuvette. Inset: variation of the molar absorptivity at two wavelengths (338 and $287 \mathrm{~nm}$ ) with the [DNA]/[complex] ratio; the lines show the fitted model to determine the binding constants of the complex with DNA. 

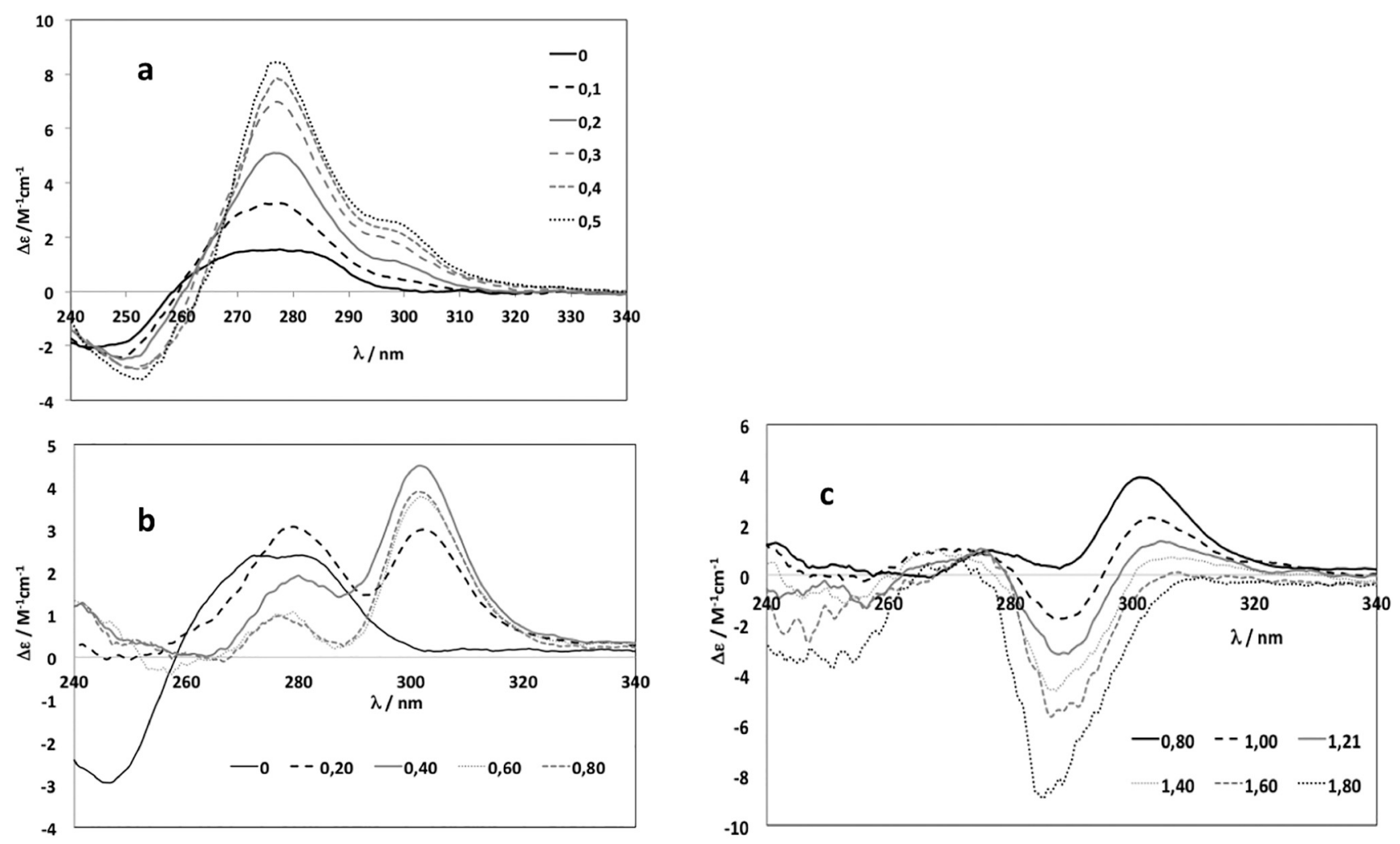

Fig. 9. Circular dichroism spectra in the UV range of solutions containing of $c t D N A$ in HEPES buffer, $\mathrm{pH} 7.4$, and increasing amounts of the zinc complexes: a) $[c t \mathrm{DNA}] \sim 65 \mu \mathrm{M}$ and addition of 6 dissolved in water; b) and c) [ctDNA] $83 \mu \mathrm{M}$ and addition of 7 dissolved in $\mathrm{MeOH}$ (max. of $5.3 \%$ ( $v / \mathrm{v}$ ) of $\mathrm{MeOH}$ up to a $1.80 \mathrm{M}$ ratio). In (c) the spectrum of $c t \mathrm{DNA}$ was subtracted. The $\Delta \varepsilon$ values are calculated based on the total ctDNA concentration.

similar, but the negative strong band at $\sim 286 \mathrm{~nm}$ only appears for higher amphen:ctDNA molar ratios (ca. 0.8-1.0) (Fig. S25), while when adding free amphen (Fig. S23) this bands only develops for still higher amphen:ctDNA molar ratios (ca. 1.2-1.4). This indicates that the $\mathrm{Zn}$-amphen species undergo speciation when added to the solution containing ctDNA (as in the case of the $\mathrm{Zn}$-phen system) and suggests that probably it is mostly the $[\mathrm{Zn}(\mathrm{amphen})]^{2+}$ complex that is binding to ctDNA. The rather distinct CD spectra obtained for the $\mathrm{Zn}$-amphen system, when compared with Zn-phen, indicates a distinct type of binding. Additionally, the changes observed in the CD spectra of Fig. $9 \mathrm{~b} / \mathrm{c}$ indicate that there is more than one binding mode for complex 7 to DNA. 7 contains amino groups that may interact with the DNA phosphate groups through $\mathrm{H}$ bonds, in the minor or major groove, which for ratios above 0.5 probably become important producing the strong negative $C D$ bands observed.

Overall, the comparison of the CD spectra of the $\mathrm{Zn}$-phen complexes and those of the corresponding free ligands show that the effects observed for incubations of complexes 6 and 7 with DNA are mostly due to the binding of $\mathrm{Zn}-\mathrm{NN}$-complexes, probably mostly $[\mathrm{Zn}(\mathrm{NN})]^{2+}$ species, and not the free ligands.

\subsubsection{Fluorescence spectroscopy}

Fluorescence emission is normally solvent dependent. For the studied systems, when $\mathbf{6}$ is excited with UV radiation it shows strong fluorescence emission in HEPES buffer of $\mathrm{pH} 7.4$, while complex 7 shows only weak emission above $500 \mathrm{~nm}$ (Fig. S26). Fig. 10 shows the emission spectra measured upon addition of ctDNA to a solution of complex 6, which highlights the strong quenching effect. The Stern-Volmer plot shows an upward curvature, suggesting that the interaction involves a mixed mechanism. At low DNA concentrations the relationship $\mathrm{I}_{\mathrm{O}} / \mathrm{l} v s$. [DNA] is linear and the Stern-Volmer constant could be obtained: $\mathrm{K}_{\mathrm{SV}}=4.30 \times 10^{3} \mathrm{M}^{-1}$. For the free phen (Fig. S27) quenching was also observed, but to a lower extent and thus a smaller SternVolmer quenching constant was determined - see Table 3. This suggests that 1,10-phenanthroline is more protected from quenching than 6 , therefore its binding probably involves intercalation, while 6, or a species derived from it, is bound to DNA in a more accessible location.

5-Amino-phenathroline and its corresponding Zn-complex, 7, were also evaluated with this technique (Fig. S27). It was interesting to observe that upon binding of amphen to ctDNA there was a decrease of the emission at $440-490 \mathrm{~nm}$, which was accompanied by the appearance and increase of a broad-band emission centered at ca. $570 \mathrm{~nm}$, probably due to excimer (excited dimer) formation [85]. This has been observed for 1,2-bis(1,10-phenanthrolin-2-yl) ethylenediamine upon interaction with DNA [86]. These authors concluded that the binding did not involve intercalation since this would preclude the formation of the excimer. Grove binding of amphen to DNA is therefore the most likely binding mode, since in this way two amphen molecules can interact in the excited state. For 7 the weak emission band centred at $594 \mathrm{~nm}$, probably due to excimer formation even in the absence of DNA, also suffers enhancement upon addition of the nucleic acid and a blue shift of $c a$. $10 \mathrm{~nm}$ (Fig. S27). It was not possible to obtain the Stern-Volmer quenching constant, due to the overlap with the excimer emission, which introduces errors. Instead, Stern-Volmer enhancement constants were calculated for amphen and $\mathbf{7}$ that are included in Table 3. It can be concluded that the type of binding of the ligands and respective $\mathrm{Zn}$-complexes differs, since the $\mathrm{K}_{\mathrm{sv}}$ constants are quite different. 5-Amino-1,10-phenanthroline binds DNA through a process that enables the formation of exited dimers, thus we suggest groove binding. This is possibly the binding mode of 7 , but 

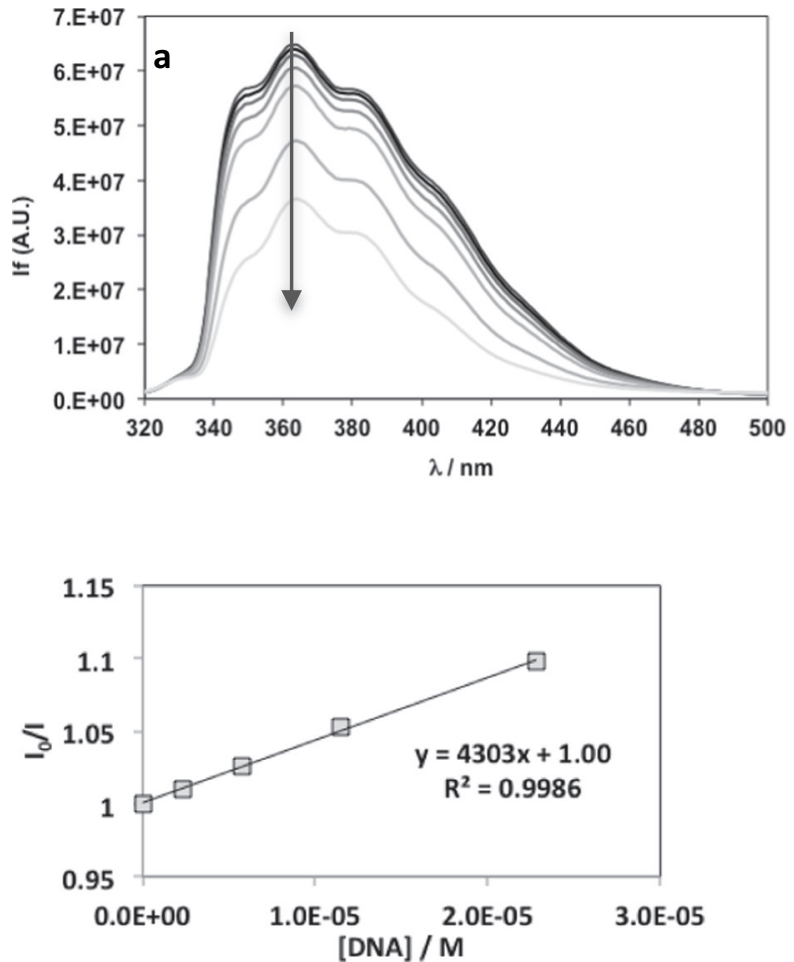

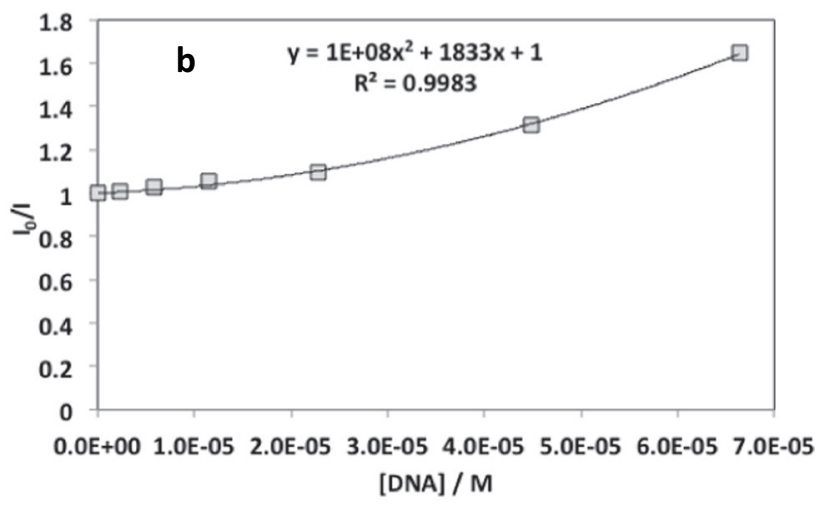

[DNA] / M

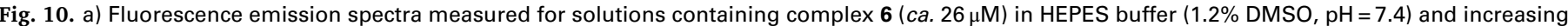

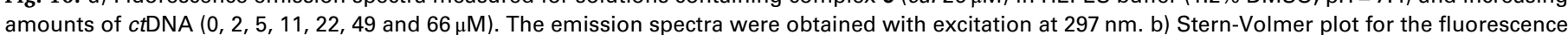
quenching ( $\mathrm{I}_{\mathrm{O}} / \mathrm{l}$ data were corrected for inner filter effects), $\lambda_{\mathrm{em}}{ }^{\max }=356 \mathrm{~nm}$. Inset: Stern-Volmer plot obtained at low $c t D N A$ concentrations.

with lower efficiency.

\subsection{Effect of serum proteins present in cell culture medium}

Many studies on the cytotoxic activity of ternary Zn-complexes containing phen ligands can be found in the literature, however they usually do not evaluate the hydrolytic stability of the complexes, or take into account the speciation that occurs in cell culture media at the low concentrations at which complexes usually are tested or may be biologically relevant. The present study clearly evidences that the original $\left[\mathrm{Zn}(\mathrm{SalGly})(\mathrm{NN})\left(\mathrm{H}_{2} \mathrm{O}\right)\right]$ complex suffers hydrolysis upon dissolution in aqueous media, possibly yielding $[\mathrm{Zn}(\mathrm{NN})]^{2+},[\mathrm{Zn}(\mathrm{NN})(\mathrm{Gly})]^{+}$, as well as other species. Cell culture media typically contains sugars, amino acids, serum proteins and redox agents, which impact metal speciation. Amino acids and particularly albumins are relevant as they show high affinity for zinc ions and most probably affinity also for $\mathrm{Zn}$ (II) complexes and ligands. In our studies [Zn(Sal-Gly)], even if formed by loss of the NN ligand from the original complex, does not show cytotoxic activity, while $\left[\mathrm{Zn}(\mathrm{NN})_{2}\right]^{2+}$ complexes show low $I_{50}$ values. Nevertheless, the free phen ligands are also active (see Table 1), for example phen against $A 2780$ cells depicts $\mathrm{IC}_{50}=5.8 \pm 2.3 \mu \mathrm{M}$ upon $48 \mathrm{~h}$ incubation.

In cell culture media, which contain relatively high concentrations of bovine serum albumin because of addition of $10 \%$ fetal bovine serum, the speciation of these species and their relative importance may be changed as each may bind differently to albumin. Assuming that the $\mathrm{Zn}$ (II) complexes bind to BSA, the uptake by cells of $\mathrm{Zn}(\mathrm{II})$-species will then also depend on the efficacy of albumin receptors/albumin binding proteins present in the membranes of the cells to facilitate its uptake. Additionally, the different species formed that bind to albumin can somewhat modulate its uptake by cells.
Table 3

Fluorescence emission parameters.

\begin{tabular}{llll}
\hline Compound & $\% \mathrm{Q}$ or \% $\mathrm{E}^{\mathrm{a}}$ & $\mathrm{K}_{\mathrm{Sv}} / \mathrm{M}^{-1}$ & $\mathrm{R}^{2}$ \\
\hline phen & $32 \%(\mathrm{Q} @ 359 \mathrm{~nm})$ & $(1.57 \pm 0.7) \times 10^{3}$ & 0.980 \\
amphen & $154 \%(\mathrm{E} @ 570 \mathrm{~nm})$ & $(1.15 \pm 0.05) \times 10^{4}$ & 0.983 \\
$\mathbf{6}$ & $43 \%(\mathrm{Q} @ 366 \mathrm{~nm})$ & $(4.30 \pm 0.9) \times 10^{3}$ & 0.999 \\
7 & $51 \%(\mathrm{E} @ 588 \mathrm{~nm})$ & $(8.7 \pm 0.6) \times 10^{3}$ & 0.963 \\
\hline
\end{tabular}

${ }^{\mathrm{a}} \mathrm{Q}=$ quenching $\mathrm{E}=$ enhancement.

Preliminary speciation calculations in cell culture media (section SI-6) were done for 6 considering several components such as phosphate, chloride, amino acids, glutathione and BSA, taking their concentrations as given by the medium supplier. It was found that the main $\mathrm{Zn}$ (II) binders at $\mathrm{pH} 7$ are BSA and phen. We would require all formation constants of all potential ligands to properly model the speciation of $\mathrm{Zn}$ (II)- and phen-containing species in cell culture media, but overall, from the several speciation diagrams calculated, we anticipate that BSA is the main binder of these species. From these speciations several $\mathrm{Zn}$ (II)- or polypyridyl-containing species are present in cell culture media, some bound to BSA, others possibly not.

Albumin has been found to accumulate at tumor sites, and this may be used favorably in delivery of anti-cancer drugs by associating, conjugating or fusing them to albumin [87-89]. Many tumor cells have more efficient mechanisms and/or albumin-binding cellular receptors for the uptake of albumins than normal cells, and this may possibly explain why in this work we find that in general the compounds show higher selectivity for the cancer cells than for the non-tumoral V79 cell line.

A preliminary study was done aiming to evaluate the effect of the amount of FBS in the cell culture media on the cytotoxicity of complex 6, against A2780 cells. Serum is a complex mix of 


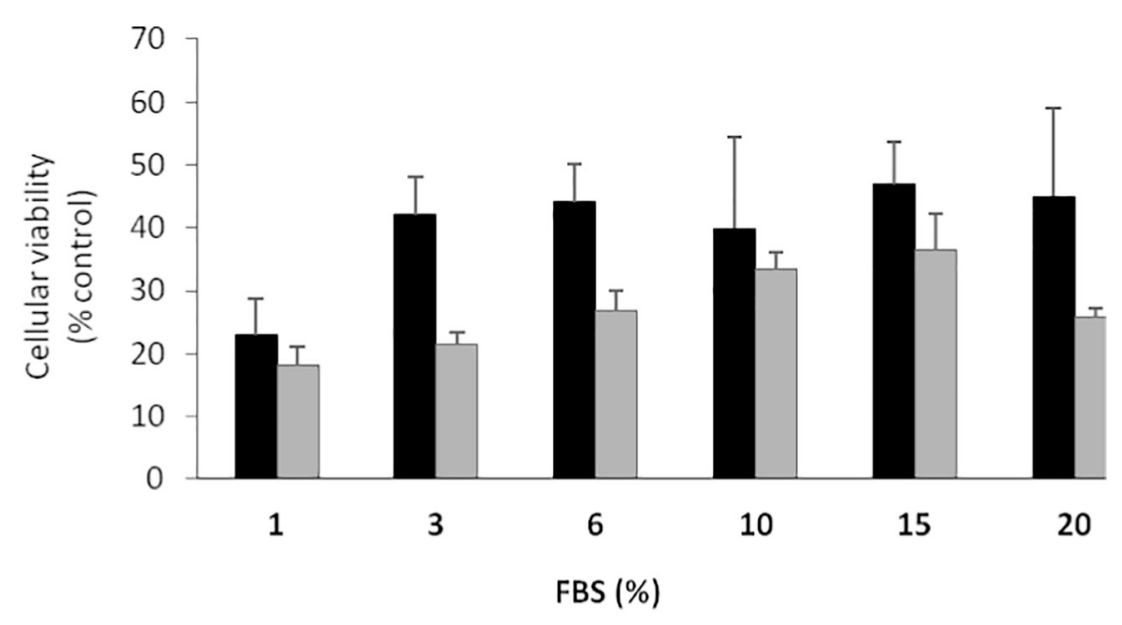

Fig. 11. Cellular viability obtained for A2780 cells incubated with complex 6, for 24 and $48 \mathrm{~h}$, in cell media containing different \% of FBS. Complex 6 was assayed at a concentration equivalent to the $\mathrm{IC}_{50}$ at $24 \mathrm{~h}(100 \mu \mathrm{M})$ and $48 \mathrm{~h}(2.4 \mu \mathrm{M})$. proteins, growth factors and growth inhibitors and is probably one of the most important components of cell culture medium. The concentration of bovine serum albumin (BSA) present in FBS is $20-36 \mathrm{mg} / \mathrm{mL}$, which is ca. $300-550 \mu \mathrm{M}$. Depending on the amount of FBS $(1-20 \%)$ used in the cell culture media the albumin concentration may vary between ca. 5 to $100 \mu \mathrm{M}$, being $\approx 40 \mu \mathrm{M}$ when the $\% \mathrm{FBS}=10 \%$. Fig. 11 depicts the results obtained in experiments varying the \% of FBS added upon 24 and $48 \mathrm{~h}$ incubation with complex 6. To check changes in the growth rate of the cells, controls were done at each \% of FBS and after examination the cells maintained viable even at lower levels of FBS.

In the cell-based studies the \% of FBS used was $10 \%$, as recommended. Varying the amount of FBS from 1 to $20 \%$, the trend observed was the same for both $24 \mathrm{~h}$ and $48 \mathrm{~h}$ incubation times, i.e., the cellular viability increases as the $\%$ of FBS increases from $1 \%$ to $15 \%$. This implies that binding to albumin in the cell media decreases the toxicity of the complexes, which is consistent with the data of Haase et al. [90] for Zn(II) salts. The cellular viability decreases for FBS at higher levels, probably because the excess serum is no longer beneficial and can actually become deleterious to the cells. If we neglect the effect of cellular growth impairment at low FBS levels, at least for $48 \mathrm{~h}$ incubation periods complex 6 seems more cytotoxic at low albumin concentrations; therefore we should not underestimate the complexity of species that may be present in the cell culture media, their interactions with albumin and the efficacy of the uptake of each by the cells.

Most probably the binding of $\mathrm{Zn}(\mathrm{II})$ to BSA is affected by the presence of phenanthroline (see sections SI-5-SI-9). [Zn(phen) $]^{2+}$ ( $n=1$ to 3 ) complexes may form [91], and besides phen, each of these may also bind to albumin. Regarding 1,10-phenanthroline, in section SI-5 (Fig. S28) fluorescence emission spectra measured at $\mathrm{pH} 7.4$ for solutions containing BSA $(6.0 \mu \mathrm{M})$ and increasing amounts of phen are depicted. The data shows that phen is able to quench the BSA fluorescence. Upon the quantitative treatment described in section SI- 5 the binding constant $\left(\mathrm{K}_{\mathrm{B}}\right)$ and number of equivalent binding sites $(n)$ determined were: $K_{B}=5.68 \times 10^{4} \mathrm{M}^{-1}$ and $n=0.6$. These values agree well with those reported by Prisecaru et al. [21], $\mathrm{K}_{\mathrm{B}}=2.54 \times 10^{4} \mathrm{M}^{-1}$ and $n=0.79$, using HEPES buffer at $\mathrm{pH}=7.2$.

In Fig. S29 and S30 we include speciation diagrams of $\mathrm{Zn}$ (II) species for total concentrations of 6 in the range 1 to $100 \mu \mathrm{M}$, for two distinct BSA concentrations $(20$ and $40 \mu \mathrm{M})$, considering the formation of $\left[\mathrm{Zn}(\text { phen })_{n}\right](n=1$ to 3$)$ and $Z n_{m}$ (BSA) $(m=1$ and 2$)$ complexes. Clearly, even not taking in consideration the plausible formation of $\left[\mathrm{Zn}(\mathrm{BSA})_{x}(\text { phen })_{y}\right]$ species, the speciation is quite complex and it is not possible at this stage to predict the impact of the speciation on the measured cytotoxic activity; however, we highlight that researchers should take these factors into account when trying to interpret their data.

As previously highlighted by some of us [92,93], conditional binding constants of labile metal complexes with most bidentate or tridentate ligands with proteins such as BSA or HSA cannot be determined by using simple fluorescence quenching methods, because at the low concentrations used these metal complexes are extensively hydrolyzed and the quenching of Trp fluorescence is due to several species and not to a single one. This is particularly relevant for metal ions, such as $\mathrm{Cu}$ (II) or $\mathrm{Zn}(\mathrm{II})$, that bind strongly to serum albumins.

\section{Conclusions}

Five mixed-ligand $\mathrm{Zn}$ (II)-complexes containing salicylaldimine and bidentate NN aromatic heterocycles were prepared and characterized in the solid state and in solution and formulated as $[\mathrm{Zn}$ $\left.(\mathrm{Sal}-\mathrm{Gly})(\mathrm{NN})\left(\mathrm{H}_{2} \mathrm{O}\right)\right]$ compounds. Two $\left[\mathrm{Zn}(\mathrm{NN})_{2}\right]^{2+}$ complexes were also synthesized and characterized. The stability of the complexes in aqueous buffered media was evaluated, showing changes consistent with hydrolysis of the Sal-Gly ligand for the [ $\mathrm{Zn}$ (Sal-Gly)(NN)( $\left.\mathrm{H}_{2} \mathrm{O}\right)$ ] compounds.

The cytotoxic activity was evaluated in a panel of human cancer cell lines: ovarian (A2780), breast (MCF7) and cervical (HeLa), as well as in non-tumoral hamster V79 fibroblasts. All compounds are more cytotoxic towards the ovarian cell line. The NN ligands and complexes 1-7 were more cytotoxic against the A2780 and MCF7 cells than the reference drug, cisplatin. Overall, all compounds show higher selectivity for the ovarian A2780 cancer cells than for the non-tumoral cell line and higher selectivity indexes than cisplatin.

The cytotoxicity data obtained for the $\left[\mathrm{Zn}(\mathrm{NN})_{2}\left(\mathrm{H}_{2} \mathrm{O}\right)_{2}\right]^{2+}$ and [ $\left.\mathrm{Zn}(\mathrm{Sal}-\mathrm{Gly})(\mathrm{NN})\left(\mathrm{H}_{2} \mathrm{O}\right)\right]$ and the $\mathrm{NN}$ ligands at $48 \mathrm{~h}$ suggest that the active species is the free NN ligand; however, studies done at different time points, and the distinct uptake and distribution of $\mathrm{Zn}$ obtained upon incubation with complexes 1, 3 and $\mathbf{6}$ show that this tentative conclusion may be an oversimplification and cannot be made in this straightforward fashion. Studies carried out with 6 by varying the FBS \% clearly showed the influence of the amount of albumin on the cell viability. Preliminary speciation calculations in cell culture media done for $\left[\mathrm{Zn}(\text { phen })_{2}\left(\mathrm{H}_{2} \mathrm{O}\right)_{2}\right]$ showed that several $\mathrm{Zn}(\mathrm{II})$ - or polypyridyl-containing species are present, some bound to BSA. It is plausible that the NN molecules are the active species, but their uptake may possibly be promoted or hampered by their binding to $\mathrm{Zn}(\mathrm{II})$ and/or albumin. The usefulness of binding polypyridyls to $\mathrm{Zn}(\mathrm{II})$ or to other metal ions depends on several factors, 
the more or less efficient uptake also depending on the type of cells.

The cellular uptake and distribution of zinc in the ovarian cancer cells, upon incubation with $\left[\mathrm{Zn}(\mathrm{Sal}-\mathrm{Gly})(\right.$ phen $\left.)\left(\mathrm{H}_{2} \mathrm{O}\right)\right](\mathbf{1})[\mathrm{Zn}(\mathrm{Sal}-$ $\mathrm{Gly})($ amphen $\left.)\left(\mathrm{H}_{2} \mathrm{O}\right)\right](3)$ and $\left[\mathrm{Zn}(\text { phen })_{2}\left(\mathrm{H}_{2} \mathrm{O}\right)_{2}\right](6)$ were analyzed by ICP-MS in cellular fractions. They present different distribution profiles, namely the nature of the NN ligand causes distinct distributions of $\mathrm{Zn}$ in different cell compartments. In the case of $1 \mathrm{ca}$. $50 \%$ of total $\mathrm{Zn}$ was retained in the cytosol, for 3 the $\mathrm{Zn}$ was equally distributed among the cellular fractions and for $6>50 \%$ was found in the cell membranes. Moreover, for complexes 1 and 6, which have similar $\mathrm{IC}_{50}$ values at $24 \mathrm{~h}$ incubation, the amount of $\mathrm{Zn}$ uptaken was much higher in the case of 1, giving indications that the cytotoxicity is not necessarily correlated with the $\mathrm{Zn}$ (II) uptake.

For complexes 1 and 3 Electronic Microscopy (TEM) provided information on the effects at cellular organelle level, giving clues on the mechanism of cell death. Apoptotic features were observed in agreement with the caspase activity detected, but for 1 the alterations typical of cell death seemed more severe. Cells incubated with [ $\mathrm{Zn}(\mathrm{Sal}-\mathrm{Gly})($ amphen $\left.)\left(\mathrm{H}_{2} \mathrm{O}\right)\right](3)$ also presented nuclear membrane indentation and larger nucleoli, which correlate with the higher accumulation found for $\mathrm{Zn}$ in the nuclei of cells incubated with 3.

To provide clues on the mechanism of cell death for this family of complexes is a challenge as the ligands that coordinate $\mathrm{Zn}$ are not just mere bystanders, and the $\mathrm{Zn}$-complexes undergo speciation as soon as added to the cell incubation medium. In fact, the NN ligands typically displayed similar or even higher cytotoxic activity than the complexes. Notwithstanding, results showed that the relative cytotoxicity depend on incubation times and cells tested, and demonstrate that complexation with $\mathrm{Zn}$ may be relevant, since the $\mathrm{Zn}$ inside the cell can also interfere with metabolism and the mitochondrial electron transport to generate ROS. The induction of apoptosis in cancer cells occurred by a mitochondrial-dependent mechanism through the electron transport system.

In this work we also highlight that the disclosure of the most relevant factors for activity of $\mathrm{Zn}-\mathrm{NN}$ complexes, namely which is the active species, is more complex than anticipated in many previous publications. A deeper understanding of speciation of metal-based drugs in cell culture media and how binding of ligands and their metal complexes to albumin affects albumin receptor binding as well as binding to membrane and cytosolic proteins is required to further advance in this field.

\section{Abbreviations}

amphen 5-amine-1,10-phenanthroline

Bphen 4,7-diphenyl-1,10-phenanthroline

Clphen 5-chloro-1,10-phenanthroline

epoxyphen 5,6-epoxy-5,6-dihydro-1,10-phenanthroline

phen 1,10-phenanthroline

Sal-Gly $\mathrm{N}$-salicylideneglycinate

ctDNA Calf Thymus DNA

BSA bovine serum albumin

XRD X-ray diffraction

XRPD X-ray Powder diffraction

FBS fetal bovine serum

HEPES 2-[4-(2-hydroxyethyl)piperazin-1-yl] ethanesulfonic acid

4-HNE 4-hydroxynonenal

MDA malondialdehyde

MTT 3-(4,5-dimethylthiazol-2-yl)-2,5-diphenyltetrazolium bromide

NBT nitro blue tetrazolium

NN polypyridyl ligand

PBS phosphate buffer saline

RLU relative luminescent units
ROS reactive oxygen species

TBA thiobarbituric acid

CD circular dichroism

ESI-MS Electrospray lonization Ionization mass spectra

ICP-MS Inductively coupled plasma mass spectrometry

TEM Transmission Electron Microscopy

SD Standard deviation

\section{Acknowledgements}

This work was supported by Fundação para a Ciência e Tecnologia (FCT) (projects UID/QUI/00100/2013, UID/MULTI/04349/ 2013, UID/BIO/04565/2013, RECI/QEQ-OIN/0189/2012, RECI/OEQMED/0330/2012), Programa Operacional Regional de Lisboa (LISBOA-01-0145-FEDER-007317). Isabel Correia thanks program Investigador FCT (IF/00841/2012), Cristina Matos, Patrique Nunes and Sónia Barroso thank FCT for grants SFRH/BD/101214/2014, SFRH/BD/108743/2015 and SFRH/BPD/7394/2010, respectively. Yemataw Addis thanks Erasmus Mundus program. The Portuguese NMR and Mass Spectrometry IST-UL Centres are acknowledged for the access to the equipment. S.B. is grateful to Centro de Química Estrutural for the access to crystallography facilities.

\section{Appendix A. Supplementary data}

Supplementary data to this article can be found online at https:// doi.org/10.1016/j.jinorgbio.2019.110727.

\section{References}

[1] S. Bhattacharyya, A. Sarkar, S.K. Dey, A. Mukherjee, J. Inorg. Biochem. 140 (2014) 131-142.

[2] A.S. Prasad, F.W.J. Beck, D.C. Snell, O. Kucuk, Nutr. Cancer 61 (2009) 879-887.

[3] J.E. Coleman, Annu. Rev. Biochem. 61 (1992) 897-946.

[4] N.C. Lim, H.C. Freake, C. Bruckner, Chem. Eur. J. 11 (2005) 38-49.

[5] W. Maret, Y. Li, Chem. Rev. 109 (2009) 4682-4707.

[6] P.U. Maheswari, S. Barends, S. Ozalp-Yaman, P. de Hoog, H. Casellas, S.J. Teat, C. Massera, M. Lutz, A.L. Spek, G.P. van Wezel, P. Gamez, J. Reedijk, Chem. Eur. J. 13 (2007) 5213-5222.

[7] C.Y. Gao, X. Qiao, Z.Y. Ma, Z.G. Wang, J. Lu, J.L. Tian, J.Y. Xu, S.P. Yan, Dalton Trans. 41 (2012) 12220-12232.

[8] E.J. Gao, T.D. Sun, S.H. Liu, S.A. Ma, Z. Wen, Y. Wang, M.C. Zhu, L. Wang, X.N. Gao, F. Guan, M.J. Guo, F.C. Liu, Eur. J. Med. Chem. 45 (2010) 4531-4538.

[9] D. Desbouis, I.P. Troitsky, M.J. Belousoff, L. Spiccia, B. Graham, Coord. Chem. Rev. 256 (2012) 897-937.

[10] S. Emami, S.J. Hosseinimehr, S.M. Taghdisi, S. Akhlaghpoor, Bioorg. Med. Chem. Lett. 17 (2007) 45-48.

[11] H. Sakurai, Y. Kojima, Y. Yoshikawa, K. Kawabe, H. Yasui, Coord. Chem. Rev. 226 (2002) 187-198.

[12] M.T. Kaczmarek, R. Jastrzab, E. Holderna-Kedzia, W. Radecka-Paryzek, Inorg. Chim. Acta 362 (2009) 3127-3133.

[13] A. Terenzi, M. Fanelli, G. Ambrosi, S. Amatori, V. Fusi, L. Giorgi, V.T. Liveri, G. Barone, Dalton Trans. 41 (2012) 4389-4395.

[14] P.F. Liguori, A. Valentini, M. Palma, A. Bellusci, S. Bernardini, M. Ghedini, M.L. Panno, C. Pettinari, F. Marchetti, A. Crispini, D. Pucci, Dalton Trans. 39 (2010) 4205-4212.

[15] Q. Jiang, J.H. Zhu, Y.M. Zhang, N. Xiao, Z.J. Guo, Biometals 22 (2009) 297-305.

[16] B.S. Mendiguchia, D. Pucci, T.F. Mastropietro, M. Ghedini, A. Crispini, Dalton Trans. 42 (2013) 6768-6774.

[17] C.M. da Silva, D.L. da Silva, L.V. Modolo, R.B. Alves, M.A. de Resende, C.V.B. Martins, Â. de Fátima, J. Adv. Res. 2 (2011) 1-8.

[18] G. Scalese, I. Correia, J. Benítez, S. Rostán, F. Marques, F. Mendes, A.P. Matos, J. Costa Pessoa, D. Gambino, J. Inorg. Biochem. 166 (2017) 162-172.

[19] C. Acilan, B. Cevatemre, Z. Adiguzel, D. Karakas, E. Ulukaya, N. Ribeiro, I. Correia, J.C. Pessoa, Biochim. Biophys. Acta Gen. Subj. 1861 (2017) 218-234.

[20] I. Correia, S. Roy, C.P. Matos, S. Borovic, N. Butenko, I. Cavaco, F. Marques, J. Lorenzo, A. Rodriguez, V. Moreno, J.C. Pessoa, J. Inorg. Biochem. 147 (2015) 134-146.

[21] A. Prisecaru, V. McKee, O. Howe, G. Rochford, M. McCann, J. Colleran, M. Pour, N. Barron, N. Gathergood, A. Kellett, J. Med. Chem. 56 (2013) 8599-8615.

[22] T.J.P. McGivern, S. Afsharpour, C.J. Marmion, Inorg. Chim. Acta 472 (2018) 12-39.

[23] R. Galindo-Murillo, J.C. Garcia-Ramos, L. Ruiz-Azuara, T.E. Cheatham, F. CortesGuzman, Nucleic Acids Res. 43 (2015) 5364-5376.

[24] T. Pivetta, F. Trudu, E. Valletta, F. Isaia, C. Castellano, F. Demartin, R. Tuveri, S. Vascellari, A. Pani, J. Inorg. Biochem. 141 (2014) 103-113.

[25] L. Ruiz-Azuara, M.E. Bravo-Gomez, Curr. Med. Chem. 17 (2010) 3606-3615. 
[26] X.C. Shi, Z.Y. Chen, Y.J. Wang, Z.J. Guo, X.Y. Wang, Dalton Trans. 47 (2018) $5049-5054$.

[27] G. Barone, A. Terenzi, A. Lauria, A.M. Almerico, J.M. Leal, N. Busto, B. Garcia, Coord. Chem. Rev. 257 (2013) 2848-2862.

[28] C. Mari, V. Pierroz, R. Rubbiani, M. Patra, J. Hess, B. Spingler, L. Oehninger, J. Schur, I. Ott, L. Salassa, S. Ferrari, G. Gasser, Chem. Eur. J. 20 (2014) $14421-14436$.

[29] D. Ambrosek, P.F. Loos, X. Assfeld, C. Daniel, J. Inorg. Biochem. 104 (2010) 893-901.

[30] S. Jagadeesan, V. Balasubramanian, P. Baumann, M. Neuburger, D. Haeussinger, C.G. Palivan, Inorg. Chem. 52 (2013) 12535-12544.

[31] G. Scalese, J. Benitez, S. Rostan, I. Correia, L. Bradford, M. Vieites, L. Minini, A. Merlino, E.L. Coitino, E. Birriel, J. Varela, H. Cerecetto, M. Gonzalez, J.C. Pessoa, D. Gambino, J. Inorg. Biochem. 147 (2015) 116-125.

[32] A. Bencini, V. Lippolis, Coord. Chem. Rev. 254 (2010) 2096-2180.

[33] Z.N. Zhao, Z.D. Luo, Q. Wu, W.J. Zheng, Y.X. Feng, T.F. Chen, Dalton Trans. 43 (2014) 17017-17028.

[34] S. Sen, S. Mitra, P. Kundu, M.K. Saha, C. Krüger, J. Bruckmann, Polyhedron 16 (1997) 2475-2481.

[35] A.J. Pallenberg, T.M. Marschner, D.M. Barnhart, Polyhedron 16 (1997) 2711-2719.

[36] G.M. Sheldrick, SADABS, Empirical Absorption Correction Program. Based on the Methods of Blessing Un. Gottingen (Ed.), (1995).

[37] M.C. Burla, R. Caliandro, M. Camalli, B. Carrozzini, G.L. Cascarano, L. De Caro, C. Giacovazzo, G. Polidori, R. Spagna, J. Appl. Crystallogr. 38 (2005) 381-388.

[38] G.M. Sheldrick, Acta Crystallogr. A 64 (2008) 112-122.

[39] L.J. Farrugia, J. Appl. Crystallogr. 32 (1999) 837-838.

[40] A.L. Spek, Acta Crystallogr. C 71 (2015) 9-18.

[41] M.N. Burnett, C.K. Johnson, J. Appl. Crystallogr. 30 (1997) 565.

[42] H.S. Choi, J.W. Kim, Y.N. Cha, C. Kim, J. Immunoassay Immunochem. 27 (2006) $31-44$.

[43] M. Munoz, R. Cedeno, J. Rodriguez, W.P.W. van der Knaap, E. Mialhe, E. Bachere, Aquaculture 191 (2000) 89-107.

[44] D.S. Miller, M. Sen, Biochem. Biophys. Res. Commun. 355 (2007) 156-161.

[45] L. Corte-Real, A.P. Matos, I. Alho, T.S. Morais, A.I. Tomaz, M.H. Garcia, I. Santos, M.P. Bicho, F. Marques, Microsc. Microanal. 19 (2013) 1122-1130.

[46] J.M. Teare, R. Islam, R. Flanagan, S. Gallagher, M.G. Davies, C. Grabau, Biotechniques 22 (1997) 1170-1174.

[47] S.R. Gallagher, F.A. Ausubel, R. Brent, R.E. Kingston, D.D. Moore, J.G. Seidman, J.A. Smith, K. Struhl (Eds.), Current Protocols in Molecular Biology, John Wiley \& Sons, New York, 1989.

[48] A. Coutinho, M. Prieto, J. Chem. Educ. 70 (1993) 425-428.

[49] J.T. Marques, R.F.M. de Almeida, J. Chem. Educ. 90 (2013) 1522-1527.

[50] T. Peters, F.W. Putman, The Plasma Proteins, Academic Press, 1975, pp. 133-181.

[51] J. Han, Y. Xing, C. Wang, P. Hou, F. Bai, X. Zeng, X. Zhang, M. Ge, J. Coord. Chem. 62 (2009) 745-756.

[52] J. Yang, J.F. Ma, Y.M. Zhang, F.F. Li, J.F. Liu, J. Coord. Chem. 56 (2003) 1409-1415.

[53] H. Erras-Hanauer, Z.W. Mao, G. Liehr, T. Clark, R. van Eldik, Eur. J. Inorg. Chem. (2003) 1562-1569.

[54] R. Mahalakshmi, N. Raman, Spectrochim. Acta A 112 (2013) 198-205.

[55] N. Raman, R. Mahalakshmi, L. Mitu, Spectrochim. Acta A 131 (2014) 355-364.

[56] K. Nakamoto, Infrared and Raman Spectra of Inorganic and Coordination Compounds: Part A: Theory and Applications in Inorganic Chemistry, Sixth edition, Wiley, 2008.

[57] D.M. Boghaei, M. Gharagozlou, Spectrochim. Acta A 67 (2007) 944-949.

[58] J.C. Pessoa, M.J. Calhorda, I. Cavaco, I. Correia, M.T. Duarte, V. Felix,
R.T. Henriques, M.F.M. Piedade, I. Tomaz, J. Chem. Soc. Dalton Trans. (2002) $4407-4415$.

[59] S.F. Mason, Inorg. Chim. Acta Rev. 2 (1968) 89-109.

[60] I. Cavaco, J.C. Pessoa, M.T. Duarte, R.T. Henriques, P.M. Matias, R.D. Gillard, J, Chem. Soc. Dalton Trans. (1996) 1989-1996.

[61] Y. Li, Z. Guo, J. Dong, L. Li, Acta Cryst. E 68 (2012) M371-M372.

[62] C.S. Lai, E.R.T. Tiekink, Appl. Organomet. Chem. 17 (2003) 197-198.

[63] J.A. Fernandes, F.A.A. Paz, F.Y. Liu, L. Cunha-Silva, L.D. Carlos, J. Rocha, Acta Cryst E66 (2010) (M1608-U1159).

[64] X.-M. Li, Q.-W. Wang, B. Liu, Acta Cryst E62 (2006) M3165-M3166.

[65] M.A. Uvarova, E.V. Kushan, S.E. Nefedov, Russ. J. Inorg. Chem. 57 (2012) 515-524.

[66] S. Khatua, S.H. Choi, J. Lee, J.O. Huh, Y. Do, D.G. Churchill, Inorg. Chem. 48 (2009) 1799-1801.

[67] D.L. Leussing, K.S. Bai, Anal. Chem. 40 (1968) 575-581.

[68] D. Hopgood, D.L. Leussing, J. Am. Chem. Soc. 91 (1969) 3740-3750.

[69] J. Valladolid, C. Hortiguela, N. Busto, G. Espino, A.M. Rodriguez, J.M. Leal, F.A. Jalon, B.R. Manzano, A. Carbayo, B. Garcia, Dalton Trans. 43 (2014) 2629-2645.

[70] S.R. Lee, Oxidative Med. Cell. Longev. (2018) 9156285(11 pages).

[71] H.T. Yang, R.M. Villani, H.L. Wang, M.J. Simpson, M.S. Roberts, M. Tang, X.W. Liang, J. Exp. Clin. Cancer Res. 37 (2018) 266-276.

[72] K.A. Conklin, Integr. Cancer Ther. 3 (2004) 294-300.

[73] D.D. Marreiro, K.J.C. Cruz, J.B.S. Morais, J.B. Beserra, J.S. Severo, A.R.S. de Oliveira, Antioxidants 6 (2017) 24-33.

[74] G.M. Bishop, R. Dringen, S.R. Robinson, Free Radic. Biol. Med. 42 (2007) $1222-1230$.

[75] C.J. Stork, Y.V. Li, Acta Neurochir. Suppl. 121 (2016) 347-353.

[76] D.R. McIlwain, T. Berger, T.W. Mak, Csh. Perspect. Biol. 5 (2013) 1-28.

[77] I.N. Lavrik, A. Golks, P.H. Krammer, J. Clin. Invest. 115 (2005) 2665-2672.

[78] K. Vermeulen, Z.N. Berneman, D.R. Van Bockstaele, Cell Prolif. 36 (2003) 165-175.

[79] C.C. Zeng, C. Zhang, S.H. Lai, H. Yin, B. Tang, D. Wan, Y.J. Liu, Inorg. Chem. Commun. 70 (2016) 210-218.

[80] H.Q. Zhong, H.Y. Yin, Redox Biol. 4 (2015) 193-199.

[81] R.L. Huang, A. Wallqvist, D.G. Covell, Biochem. Pharmacol. 69 (2005) 1009-1039.

[82] V.I. Ivanov, L.E. Minchenkova, A.K. Schyolkina, A.I. Poletayev, Biopolymers 12 (1973) 89-110.

[83] J. Costa Pessoa, I. Correia, G. Goncalves, A.I. Tomaz, J. Argent. Chem. Soc. 97 (2009) 151-165.

[84] N.C. Garbett, P.A. Ragazzon, J.B. Chaires, Nat. Protoc. 2 (2007) 3166-3172.

[85] B. Valeur, M.N. Berberan-Santos in Molecular Fluorescence: Principles and Applications (2012) Wiley.

[86] K. Hayashi, H. Akutsu, H. Ozaki, H. Sawai, Chem. Commun. (2004) 1386-1387.

[87] M. Bern, K.M.K. Sand, J. Nilsen, I. Sandlie, J.T. Andersen, J. Control. Release 211 (2015) 144-162.

[88] A. Wunder, U. Muller-Ladner, E.H.K. Stelzer, J. Funk, E. Neumann, G. Stehle, T. Pap, H. Sinn, S. Gay, C. Fiehn, J. Immunol. 170 (2003) 4793-4801.

[89] F. Kratz, K. Abu Ajaj, A. Warnecke, Expert Opin. Investig. Drugs 16 (2007) 1037-1058.

[90] H. Haase, S. Hebel, G. Engelhardt, L. Rink, Metallomics 7 (2015) 97-106.

[91] C.V. Banks, R.I. Bystroff, J. Am. Chem. Soc. 81 (1959) 6153-6158.

[92] I. Correia, S. Borovic, I. Cavaco, C.P. Matos, S. Roy, H.M. Santos, L. Fernandes, J.L. Capelo, L. Ruiz-Azuara, J.C. Pessoa, J. Inorg. Biochem. 175 (2017) 284-297.

[93] I. Correia, I. Chorna, I. Cavaco, S. Roy, M.L. Kuznetsov, N. Ribeiro, G. Justino, F. Marques, T. Santos-Silva, M.F.A. Santos, M.S.E. Hugo, J.L. Capelo, J. Doutch, J.C. Pessoa, Chem. Asian J. 12 (2017) 2062-2084. 